\title{
Interwar Period Officer Education: A Model For The Future
}

A Monograph

by

MAJ Jason S. Jones

United States Army

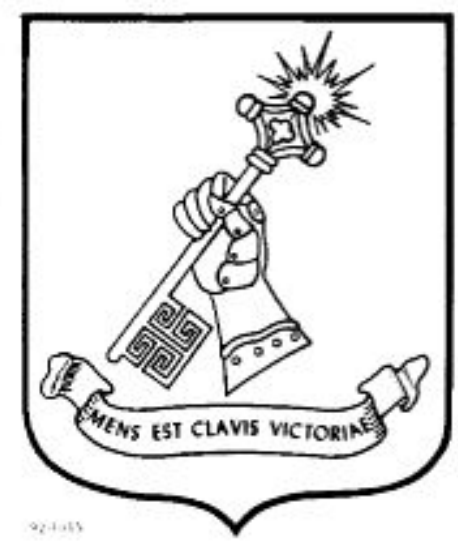

School of Advanced Military Studies

United States Army Command and General Staff College

Fort Leavenworth, Kansas

AY 2015-01

Approved for Public Release; Distribution is Unlimited 


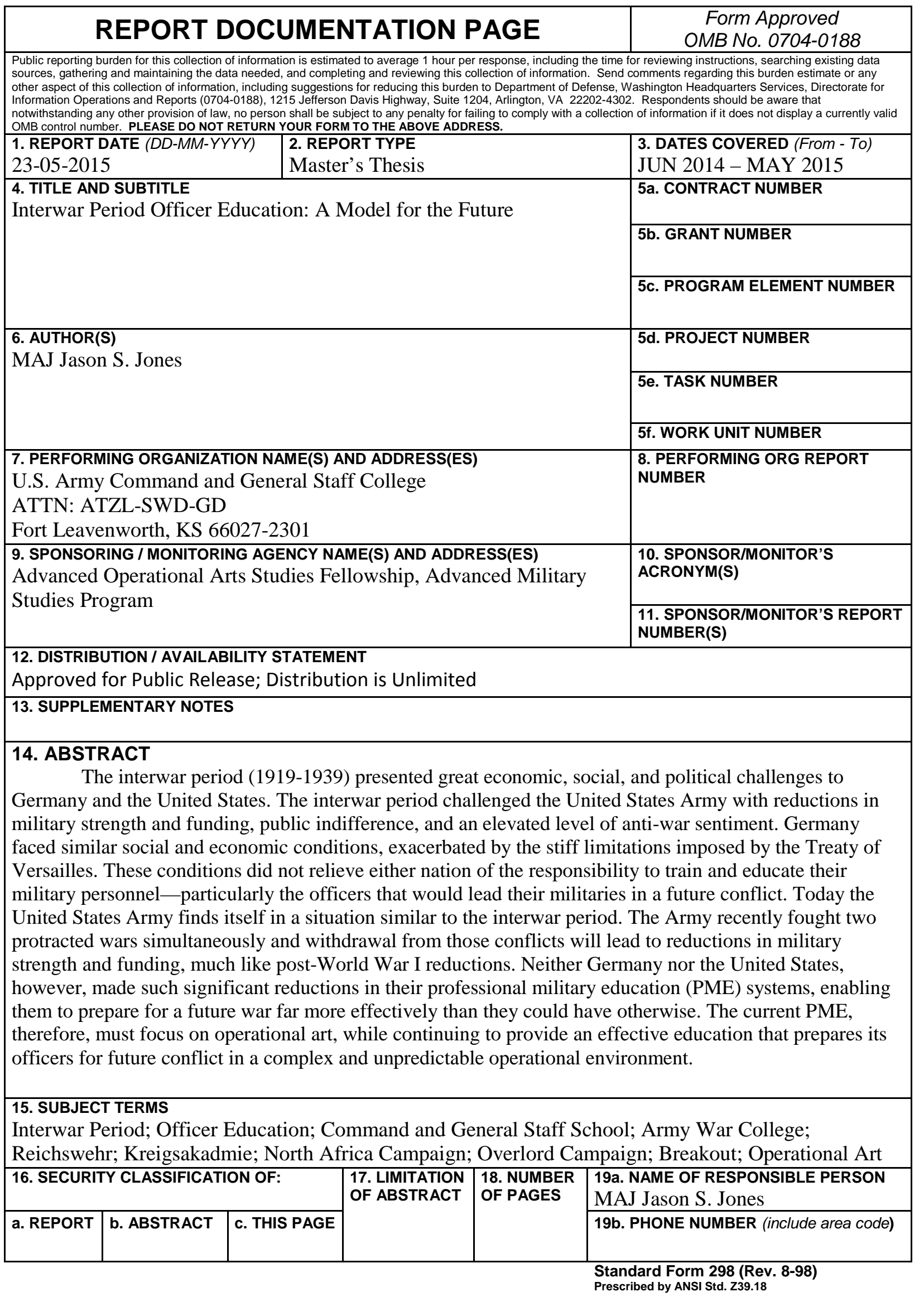




\section{Monograph Approval Page}

Name of Candidate: MAJ Jason S. Jones

Monograph Title: Interwar Period Officer Education: A Model for the Future

Approved by:

Monograph Director

Mark T. Calhoun, PhD

, Seminar Leader

Michael D. Rayburn, COL

, Director, School of Advanced Military Studies

Henry A. Arnold III, COL

Accepted this 23rd day of May 2015 by:

Robert F. Baumann, PhD

, Director, Graduate Degree Programs

The opinions and conclusions expressed herein are those of the student author, and do not necessarily represent the views of the U.S. Army Command and General Staff College or any other government agency. (References to this study should include the foregoing statement.) 


\begin{abstract}
Interwar Period Officer Education: A Model for the Future, by MAJ Jason S. Jones, 54 pages.

The interwar period (1919-1939) presented great economic, social, and political challenges to Germany and the United States. The interwar period challenged the United States Army with reductions in military strength and funding, public indifference, and an elevated level of anti-war sentiment. Germany faced similar social and economic conditions, exacerbated by the stiff limitations imposed by the Treaty of Versailles. These conditions did not relieve either nation of the responsibility to train and educate their military personnel—particularly the officers that would lead their militaries in a future conflict. Neither Germany nor the United States, however, made such significant reductions in their professional military education (PME) systems, enabling them to prepare for a future war far more effectively than they could have otherwise. Today the United States Army finds itself in a situation similar to the interwar period. The Army recently fought two protracted wars simultaneously and withdrawal from those conflicts will lead to reductions in military strength and funding, much like post-World War I reductions. The current United States Army's PME system remains as important today as it proved to be in 1939 in the preparation for future contingencies requiring the use of military force. Analysis of both the North African campaign and the Normandy breakout in World War II provide confirmation of the value of officer education in enabling success in warfare. The current PME, therefore, must focus on operational art, while continuing to provide an effective education that prepares its officers for future conflict in a complex and unpredictable operational environment.
\end{abstract}




\section{Contents}

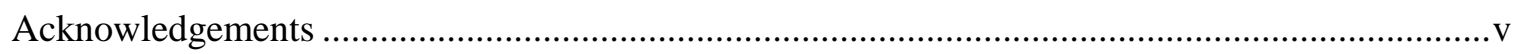

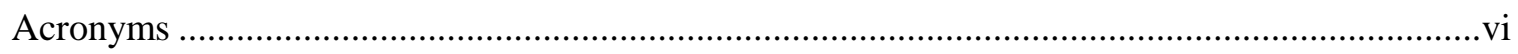

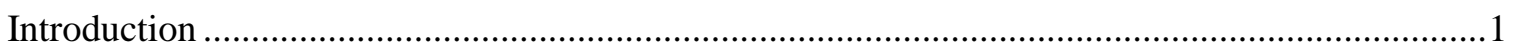

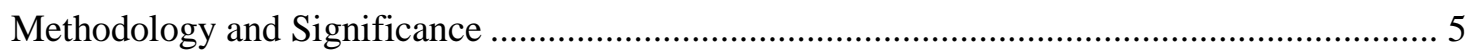

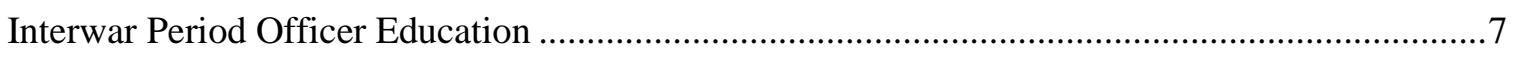

Command and General Staff School and Army War College .............................................. 7

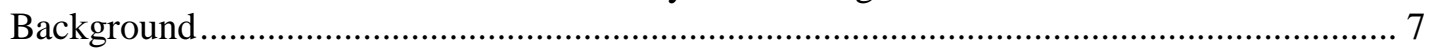

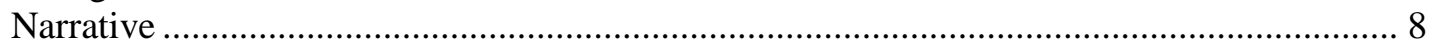

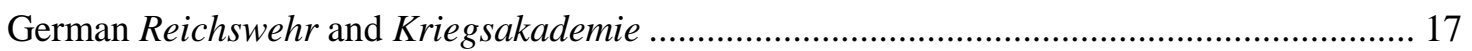

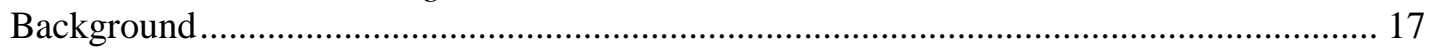

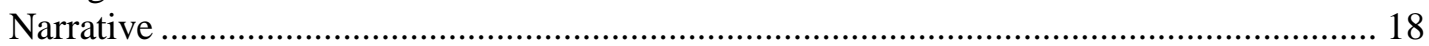

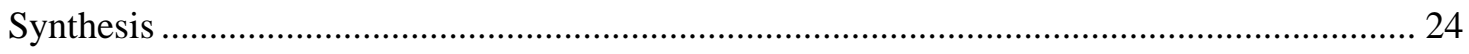

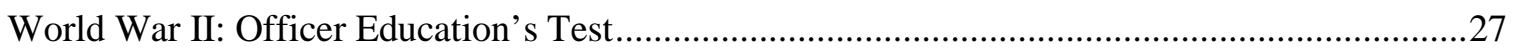

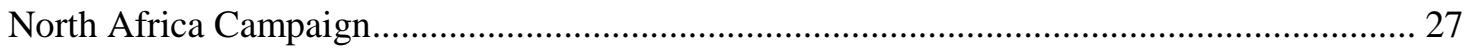

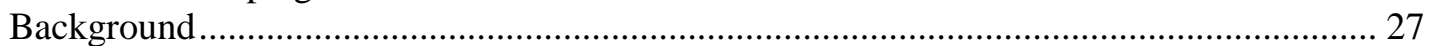

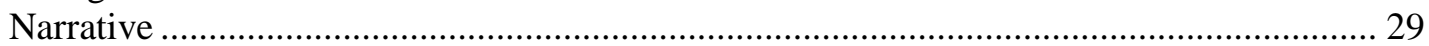

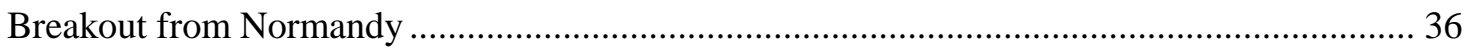

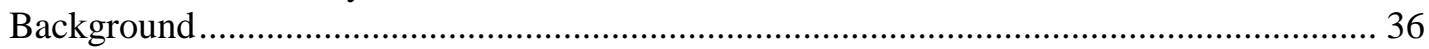

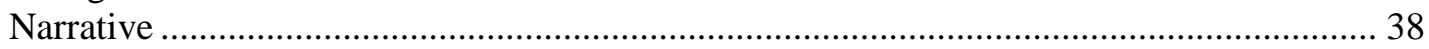

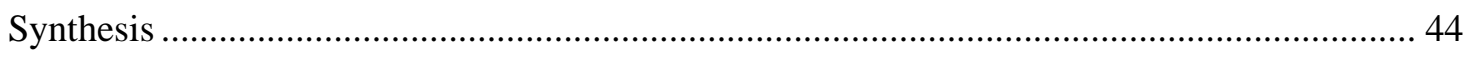

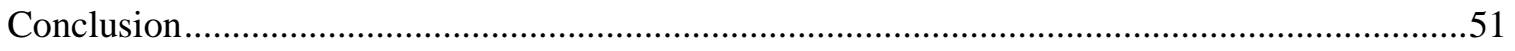

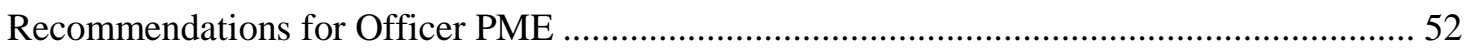

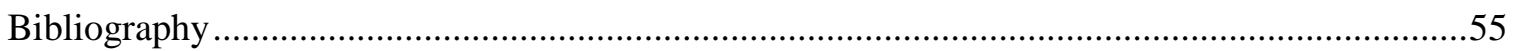




\section{Acknowledgements}

I would like to express my gratitude to my director, Dr. Mark Calhoun and seminar leader, Colonel Michael Rayburn for their guidance and patience in providing an excellent environment to research, write, and learn. I would like to thank Majors Brett Bardo and Todd Poindexter, who as vigilant friends always provided help, suggestions, and confidence boosts when needed the most. Above all, I want to thank my daughter Bailey. She sacrificed many visits,

phone calls, and video messages; despite this, she always supported and encouraged me. I could never have accomplished this without her. 


\section{Acronyms}

$\begin{array}{ll}\text { ADP } & \text { Army Doctrinal Publication } \\ \text { AEF } & \text { American Expeditionary Force } \\ \text { AWC } & \text { Army War College } \\ \text { CGSS } & \text { Command and General Staff School } \\ \text { PME } & \text { Professional Military Education } \\ \text { SHAEF } & \text { Supreme Headquarters Allied Expeditionary Forces } \\ \text { TRADOC } & \text { Training and Doctrine Command }\end{array}$




\section{Introduction}

The interwar period (1919-1939) presented great economic, social, and political challenges to both Germany and the United States. ${ }^{1}$ The United States retreated to isolationism after its involvement in World War I—a costly war that most citizens wanted the nation to avoid — which resulted in reductions in military strength and funding, and a general feeling of anti-war sentiment within the nation. ${ }^{2}$ At the end of World War I, many military leaders, including General Pershing, not only understood the likelihood of another major war eventually breaking out in Europe, but also realized that America's involvement would require the mobilization of the entire nation. ${ }^{3}$ However, faced with no impending military threat, Congress passed the National Defense Act of June 4, 1920. This legislation only authorized funding for a standing army half the size of that recommended by senior military leaders and provided the framework for defensive mobilization of the Army should a significant threat warrant a military response. Not only did Congress authorize a smaller army than military leaders advised; it

${ }^{1}$ For accounts on the political, social, and economic challenges faced by the United States see David M. Kennedy, Over Here: The First World War and American Society (New York: Oxford University Press, 1980), 230-369; Pendleton Herring, The Impact of War: Our American Democracy Under Arms (New York: J.J. Little and Ives, 1941); Michael Pearlman, To Make America Safe for Democracy: Patricians and Preparedness in the Progressive Era (Chicago: University of Illinois Press, 1984), 145-226; David M. Kennedy, Freedom from Fear: The American People in Depression and War, 1929-1945 (New York: Oxford University Press, 1999); Paul A.C. Koistinen, The Hammer and the Sword (New York: Arno Press, 1979), 1-78;

Paul A.C. Koistinen, Planning War, Pursuing Peace, vol. 2, The Political Economy of American Warfare, 1920-1939 (Lawrence: University Press of Kansas, 1998).

${ }^{2}$ Michael R. Matheny, Carrying the War to the Enemy: American Operational Art to 1945 (Norman: University of Oklahoma Press, 2011), 45-46.

${ }^{3}$ Peter J. Schifferle, America's School for War: Fort Leavenworth, Officer Education, and Victory in World War II (Lawrence: University of Kansas Press, 2010), 14-17. 
underfunded the already small army each year making modernization impossible and training a challenge. ${ }^{4}$

To contend with the chronic lack of resources and funding for training and manpower, the leaders of the United States Army turned to education and training —-what the United States government now calls professional military education (PME)— to implement the lessons from World War I. This meant that the Army became a "schoolhouse"-a term used to describe this new, small, and underfunded Army’s mission: to prepare the officers that would lead and educate draftees in the event of a mobilization for war. ${ }^{5}$ This primary responsibility rested on the shoulders of the Command and General Staff School (CGSS) at Fort Leavenworth, Kansas, and the Army War College (AWC) in Washington, DC.

In America's School for War: Fort Leavenworth, Officer Education, and Victory in World War II, Peter Schifferle examined how CGSS trained and educated officers to implement the lessons of World War I and prepare for "the inevitable War of the Future.”“ Schifferle demonstrated the education provided at CGSS during the interwar period set the conditions for success of the US Army in World War II. Schifferle's work provides an in-depth analysis of American officer military education system between the wars and its contribution to success in warfare.

Historians often claim that before and during World War II, the US Army had little understanding of operational art. ${ }^{7}$ In Carrying the War to the Enemy: American Operational Art

\footnotetext{
${ }^{4}$ Schifferle, America's School for War, 17-19; Martin Blumenson, "Kasserine Pass, 30 January-22 February 1943,” in America's First Battles, 1776-1965, ed. Charles E. Heller and William A. Stoft (Lawrence: University Press of Kansas, 1986), 227-28.

${ }^{5}$ Schifferle, America's School for War, 17.

${ }^{6}$ Ibid., 14.

${ }^{7}$ Russell F. Weigley, “Normandy to Falaise: A Critique of Allied Operational Planning in 1944," in Historical Perspectives of the Operational Art, ed. Michael D. Krause and R. Cody Phillips (Washington, DC: Center for Military History, 2007), 409-10; Martin Blumenson, “A
} 
to 1945, Michael Matheny argued that the ability of American commanders to coordinate combined arms and joint operations at the operational level displayed a clear understanding of operational art. ${ }^{8}$ Furthermore, he argued the education received at CGSS and the AWC during the interwar period served as the basis for this understanding. ${ }^{9}$ Matheny's detailed analysis helps to isolate the elements of operational art that officers studied at CGSS and AWC, and how these officers, serving later as staff officers and commanders, successfully used them in World War II. While the US Army dealt with internally imposed difficulties, in contrast, Germany's military faced limitations the great powers imposed on the nation after the First World War.

Stiff limitations imposed by the Treaty of Versailles exacerbated Germany’s volatile social and economic conditions. The Treaty reduced the German military in size, disposition, and capabilities, allowing it to conduct limited internal and national defense only. Article 176 of the treaty severely limited German professional military education. ${ }^{10}$ The article abolished the German Kriegsakademie and the traditional purpose of preparing officers for command and service on the German General Staff. The treaty intended for German officer education to enable officer recruitment and service sustainment only. ${ }^{11}$ Germany circumvented the treaty, however, and did not close the school. Instead, Germany changed its name and hid its formal existence

Deaf Ear to Clausewitz: Allied Operational Objectives in World War II," The U.S. Army War College Quarterly: Parameters 23, no. 2 (Summer 1993): 16-27.

${ }^{8}$ Matheny, Carrying the War to the Enemy, xx.

${ }^{9}$ Ibid.

${ }^{10}$ Richard Hacken and Jane Plotke, “Peace Treaty of Versailles: Articles 159 - 213,” last modified November 11, 1998, accessed September 25, 2014, http://net.lib.byu.edu/ rdh7/wwi/ versa/versa4.html.

${ }^{11}$ Ibid. 
until 1935. ${ }^{12}$ Therefore, until 1935, the management and administration of German officer education was the direct responsibility of the German Reichswehr. ${ }^{13}$

The social, political, and economic obstacles faced by the United States and Germany did not relieve either nation of the responsibility to train and educate their military personnel, particularly the officers that would lead their militaries in a future conflict. Today the US Army finds itself in a situation similar to the interwar period. The Army recently fought two protracted wars simultaneously and the anticipated withdrawal from those conflicts has led to announcements of reductions in military strength, funding, and officer professional military education, much like the post-World War I reductions. ${ }^{14}$

The modern US Army’s reductions in military strength, funding, and officer PME have much in common with those of the interwar period of 1919 to 1939, making these two decades useful as sources for comparative analysis. For example, the American and German armies that fought WWII each overcome economic obstacles much like the US Army faces today to develop effective professional officer education programs, and one can learn from each army’s approach

12 Jörg Muth, Command Culture: Officer Education in the U.S. Army and the German Armed Forces, 1901-1940 and the Consequences for World War II (Denton, TX: University of North Texas Press, 2011), 12.

${ }^{13}$ Robert Citino, The Path to Blitzkrieg: Doctrine and Training in the German Army, 1920-1939 (Boulder, CO: Lynne Reinner Publishers, 1999). Citino wrote a detailed examination of the manner in which Germany manned, educated, trained, and equipped the German army despite the limitations imposed by the Treaty of Versailles. Citino argued that the reforms Germany made in doctrine and education during the interwar period aided in setting the conditions for the initial success of combined arms mechanized warfare.

${ }^{14}$ For more on the projected Department of Defense budget for 2015 and the troop reductions it will require see Leon E. Panetta and Barack Obama, Sustaining Global Leadership: Priorities for the $21^{\text {st }}$ Century Defense (Washington, DC: Government Printing Office, 2012); Office of Management and Budget, Fiscal Year 2015 Budget of the U.S. Government (Washington, DC: Government Printing Office, 2014), 57-63; Tom Shanker and Helene Cooper, "Pentagon Plans to Shrink Army to Pre-World War II Level," New York Times, February 23, 2014, accessed March 14, 2015, http://www.nytimes.com/2014/02/24/us/politics/pentagon-plansto-shrink-army-to-pre-world-war-ii-level.html?_r=0; Training and Doctrine Command (TRADOC) Pamphlet 525-3-0, The U.S. Army Capstone Concept (Fort Eustis, VA: Headquarters, Training and Doctrine Command, 2012). 
to this problem. Not only did the armies need these school systems; they needed them to create effective leaders in the event of an outbreak of conflict. Specific elements of the curriculum of the Command and General Staff School (CGSS), the Army War College (AWC), the German Reichswehr, and the German Kriegsakademie contributed to each army’s effectiveness in warfare - this provides another valuable source of insight for comparative analysis. In addition to curricula, culture and climate play a significant role in officer education, making these important aspects of the two nations' officer education systems. Study of these aspects of the American and German interwar officer education systems facilitates analysis of the research question: to what degree each nation's officer education system contributed to success in warfare during WWII.

The current US Army's PME system employs various educational methods, including the study of past wars to improve preparation for various possible future contingencies requiring the use of military force. The Army's recent shift in educational emphasis towards unified land operations and the offense and defensive competencies of decisive action creates challenges as the Army emerges from thirteen years of immersion in conflicts that consisted primarily of counterinsurgency operations. ${ }^{15}$ The current PME, therefore, must shift within an operational art focus, while continuing to provide an effective education that prepares its officers for future conflict in a complex and unpredictable operational environment.

\section{Methodology and Significance}

This monograph explores the research question from a multiple case study approach, using cross-case analysis as a source of evidence to prove the validity of the thesis. The

${ }^{15}$ For background on the US Army's recent shift in emphasis from counterinsurgency operations to unified land operations and the core competencies of decisive action see TRADOC Pamphlet 525-3-0; David Crozier, "Decisive Action: How to Fight and Sustain in the Army's Future Battles,” NCO Journal, May 28, 2013, accessed January 21, 2015, http://ncojournal. dodlive.mil /2013/05/28/decisive-action-how-to-fight-and-sustain-in-the-armys-future-battles/. 
previously identified research questions provide entry-level arguments that guide research and analysis. Comparison of American and German interwar military education systems— specifically, the American Command and General Staff School and AWC, and the German Reichswehr and Kriegsakademie reveal similarities and differences in the two nations’ approaches to officer education during the interwar period.

Two case studies-American operations in North Africa, and Operation Cobra, the American role in the major breakout effort that finally restored maneuver to the battlefield in Western Europe-demonstrate the manner in which the interwar education systems translated into performance on the battlefield. Three elements of operational art, center of gravity, phasing and transitions, and risk serve as the criteria to enable an objective comparison of the strengths and weaknesses of the American and the German Armies in combat, and provide a connection to the interwar education systems enabling identification of the key factors that differentiated the two armies' ability to conduct operational art. ${ }^{16}$ Comparative analysis of the American and German interwar period military education systems, viewed through the lens of the performance of their graduates during two World War II campaigns, illustrates fundamental principles that will assist the transformation of the modern US Army’s PME system, so graduates can conduct operational art in all forms of decisive action. The analysis of these key factors, once synthesized, highlights implications and recommendations for the direction of contemporary US Army officer PME.

${ }^{16}$ For definitions of operational art and its supporting elements see Army Doctrine Reference Publication (ADRP) 3-0, Unified Land Operations (Washington, DC: Government Printing Office, 2012), 4-1-4-9. 


\section{Interwar Period Officer Education}

Command and General Staff School and Army War College

\section{Background}

Operational requirements, limited funding, popular opinions about the military and war, as well as pre-war mobilization at the beginning of American involvement in World War I left officer professional military education in dire conditions. The operational requirements not only required many Regular Army and National Guard officers, it also drew a large number of its officers from the instructor positions that enabled the officer military education system to accomplish its mission. ${ }^{17}$ Additionally, with American involvement in World War I on the horizon, the War Department slowed the function of CGSS and AWC from 1914-16 and then closed the schools in 1917 to support mobilization efforts. ${ }^{18}$

When the mobilization for World War I began, the now vastly expanded army found itself lacking an adequate number of officers capable of strategic and operational level thinking, as well as formal general staff training at the division echelon and higher. Therefore, the slowed functioning of the schools only emerged as a significant problem when the US Army initiated mobilization and expansion for World War I. Many of those who had the "Leavenworth"

${ }^{17}$ For more on the US Army before its entrance into World War I see Mark E. Grotelueschen, The AEF Way of War: The American Army and Combat in World War I (New York: Cambridge University Press, 2007), 24; John Patrick Finnegan, Against the Spector of a Dragon: The Campaign for Military Preparedness, 1914-1917 (Westport, CT: Greenwood Press, 1974) 8-20, 42-56. Grotelueschen provides a short narrative regarding the closing of the US Army Field Artillery training and experimentation center, which educated artillery officers, in order to support operational requirements for the Punitive Expedition.

${ }^{18}$ Timothy. K Nenninger, “A Brief Account of the Evolution of the Regular Course at the U.S. Army Command and General Staff College” (Special Collections, Ike Skelton Combined Arms Library, 1988). Nenninger's analysis provides a streamlined guide on the evolution of the regular course from 1880-1988. In various time increments, Nenninger addressed the duration of the course, the curriculum focuses, class size and composition, as well as the outside influences and purposes for the numerous course changes. 
education found themselves initially assigned to the American Expeditionary Force (AEF) General Headquarters staff, leaving few to serve at the division level. ${ }^{19}$

General Pershing, who appreciated the Leavenworth education, understood that the AEF faced a new challenge on the modern battlefields of Western Europe ${ }^{20}$ Directed by Pershing to find a way to continue officer education among mobilizing AEF units, Colonel Hugh Drum recommended in 1917 that the AEF create a staff school at Langres, France modeled after CGSS. ${ }^{21}$ The staff school at Langres, although much shorter than CGSS, focused on problem solving and general staff operations at the division level, increasing the overall competence of AEF officers. ${ }^{22}$ However, the school at Langres provided only a temporary fix to an issue that required a formal system for officer education. Through the creation of a centralized and deliberate officer education program, the Army could maintain an adequate number of school trained officers to serve as cadre to train and educate a mobilized and expanded army in support of any future mobilization efforts. With this impetus, the US Army leadership recognized the need to reestablish and redesign the officer education system as a whole upon its return to the United States, specifically the education of field grade officers at the AWC and CGSS.

\section{Narrative}

The curriculum taught in the interwar period at CGSS and the AWC owed its origins to four significant review boards. The first of these boards, the AEF Superior Board on Organization and Tactics held in April 1919 synthesized the findings of smaller and more specialized boards.

${ }^{19}$ Schifferle, America's School for War, 10.

${ }^{20}$ Ibid., 10-11.

${ }^{21}$ Schifferle, America's School for War, 11. The AEF modeled the Langres school after CGSS at Fort Leavenworth with modifications to integrate the AEF Staff system with the British and French staff systems.

${ }^{22}$ Ibid., 13. 
According to Michael Matheny, “the board confirmed the AEF’s staff organization (and recommended its formation at the battalion level), unity of command, importance of logistics, supremacy of the infantry, and the offensive spirit." ${ }^{23}$ This not only embraced the change in warfare that evolved because of World War I, it also highlighted key aspects that fueled the American understanding of operational art during World War II.

However, a significant level of disagreement existed amongst the board members, which manifested in their recommendations. The board consisted of divided groups made up of those who favored either the existing prewar doctrine, the employment of massive firepower as the primary means of conducting warfare, or the importance of firepower employed in a supporting role, while recognizing the infantry's continued place of primacy within the Army's combat formations. ${ }^{24}$ Further fueling the division amongst the senior leaders of the Army, General Pershing finally approved the Superior Board Report for release six months after the board completed it, but only after including his own “Wrapper Indorsement.” Pershing’s indorsement significantly affected the delivery and interpretation of the board's findings upon its submission to the secretary of war in 1920. Despite the opinions of Pershing and those who supported various interpretations of the Superior Board's findings, a general consensus emerged amongst the senior leaders regarding one key concept: the need to develop a maneuver centric combined arms capability in the US Army. ${ }^{25}$ This laid the foundation for other boards and doctrinal reviews that reorganized the curriculum of CGSS and AWC throughout the interwar period.

${ }^{23}$ Matheny, Carrying the War to the Enemy, 46-47.

${ }^{24}$ Grotelueschen, The AEF Way of War, 353-54.

${ }^{25}$ Grotelueschen, 354-60. Pershing believed that the members of the board were too heavily influenced by their individual experiences during the war. Their beliefs, in general, conflicted with Pershing's determination to avoid the stabilized fronts that dominated World War I in Western Europe by focusing on maneuver-centric combined arms warfare. As a result of the Superior Board, Pershing became more involved with the board processes that restructured US Army doctrine during his tenure as Army Chief of Staff. 
The McGlachlin board of 1922 sought a means to maintain a high quality officer education system while accounting for the manning and financial restrictions imposed by the National Defense Act of 1920. The board was chaired by a well-qualified officer. Before the mobilization for World War I, Major General Edward McGlachlin served as commandant of the Artillery School and during the war, he commanded the First US Army’s artillery regiment. ${ }^{26}$ These two formative experiences made him very well suited to serve as the board's chairman. The board recommended changes to student selection and evaluations, training tour lengths, and the minimum service time between attendance to CGSS and AWC. According to historian Peter Schifferle, the board recommended that "the School of the Line be continued as a one-year program, followed by the General Staff School, with duration there limited to only six months.”27 Despite the findings, a high level of dissent remained amongst the board members concerning the recommendations; particularly from Colonel Harold Fiske, whose objections, led to the acceptance of only part of the board's recommendations. ${ }^{28}$

To sort out the dissent, Pershing and the War Department appointed Fiske to lead a third board in July 1922, just five months after the McGlachlin Board's conclusion. ${ }^{29}$ The Fiske board made distinct recommendations for the restructuring of branch specific schools, CGSS, and AWC that synthesized all existing board recommendations into a unified solution for the future of

${ }^{26}$ Harry P. Ball, Of Responsible Command: A History of the U.S. Army War College (Carlisle Barracks, PA: The Alumni Association of the United States Army War College, 1984), 176.

${ }^{27}$ Schifferle, America's School for War, 33.

${ }^{28}$ Ball, Of Responsible Command, 183-85; Schifferle, America's School for War, 33-34. Colonel Fiske was the chief of training for the AEF from February 1918 until the end of the war. At the time of the McGlachlin board, he served as the Chief of Training Branch, War Department G-3. Pershing handpicked Fiske and he aligned with Pershing's goals for doctrine and educational change in the US Army following World War I. Fiske's “Minority Report” listed several disagreements to the recommendation of the McGlachlin board.

${ }^{29}$ Ball, Of Responsible Command, 194-95; Schifferle, America's School for War, 34. 
officer education. The main recommendation dealt with establishing clear distinctions between the subject matter of the branch specific schools, CGSS, and the AWC. The board dictated that the curriculum of CGSS would address tactical and operational level subjects at the corps level and below. ${ }^{30}$ The AWC would address strategic issues, joint and combined operations, as well as mobilization planning to develop officers for service and command up to the field army level and the War Department General Staff. ${ }^{31}$

In December 1927, Chief of Staff of the Army General Charles Summerall reversed Pershing's decisions in relation to the McGlachlin, Fiske, and Ely boards. ${ }^{32}$ Based on the recommendations of the Ely board, Summerall directed the reestablishment of CGSS as a twoyear program and affirmed that the AWC would maintain the responsibility of instruction in field army operations and higher. ${ }^{33}$ Based on this, the AWC expanded its scope. This change included both training staff officers and future commanders in field army operations and joint operations, and instruction in the social, political, and economic factors of war, strategy, tactics, and the logistics of large operations. ${ }^{34}$ Given the timing of the Ely board and the scope of the changes it advised, Major General William Connor, Commandant of the AWC, put into effect a new curriculum in line with this guidance during the 1928 to 1929 academic year, the same year that Generals Dwight D. Eisenhower and Lesley J. McNair attended the AWC. During the first half of the year, the class focused on the Preparation for War; during the second half, it focused on the

${ }^{30}$ Ball, Of Responsible Command, 194-95; Schifferle, America's School for War, 34.

${ }^{31}$ Timothy K. Nenninger, "Leavenworth and Its Critics: The U.S. Army Command and General Staff School, 1920-1940,” The Journal of Military History 58, no. 2 (April 1994): 20203; George S. Pappas, Prudens Futuri: The US Army War College, 1901-1967 (Carlisle Barracks, PA: The Alumni Association of the US Army War College, 1967), 90.

32 Ball, Of Responsible Command, 210.

${ }^{33}$ Ibid.

${ }^{34}$ Ibid., 213. 
Conduct of War. ${ }^{35}$ This highlighted the relationship between planning and execution of war, the relationship between service on general staffs and in command, and therefore, emphasized the relationship between the three levels of war and operational art.

These four boards' recommendations laid an institutional and doctrinal foundation for mid-grade officer education. This foundation, supported by the 1925 publication of Army Regulation 350-5 Training, solidified CGSS and the AWC as key institutions in the US Army's education system, giving them each a clear mission and focus until mobilization began in $1940 .{ }^{36}$ Although branch specific and other army courses provided the basic education to army officers, CGSS and the AWC brought together field grade officers throughout the army to learn to work as staffs and commanders at various echelons. This proved vital to the army’s success from mobilization to victory in World War II. Additionally, the publication of the 1923 Field Service Regulations, the 1939 Field Service Regulations, and the 1941 Field Manual 100-5 Operations, ensured that CGSS and the AWC always had approved and comprehensive doctrine on which to base their systems of education and training. Therefore, the army accounted for and overcame the restrictions imposed by the National Defense Act of 1920 and developed doctrinal based curriculums that enabled success for students, as well as the Army in World War II.

Although the duration of CGSS during the interwar period changed based on various War Department directed requirements, the curriculum remained consistent and grounded in the governing doctrine of the period. CGSS curriculum centered on command and general staff functions at the reinforced brigade, division, and corps echelons - the realm of tactics. During the years when it offered a second-year course, the General Staff School also taught operations at the field army level to those officers selected to attend. Regardless of the duration of the course,

\footnotetext{
35 Ball, Of Responsible Command, 213.

${ }^{36}$ Schifferle, America's School for War, 35.
} 
subject matter included instruction on tactics, techniques, capabilities, and limitations on each of the army's separate arms, complex tactical problems centered on large combined arms formations, campaign planning, history, military theory. The schools also placed special emphasis on the command process—-significantly, from both the commander's and the general staff officer's perspective. ${ }^{37}$ Additionally, Matheny asserted that CGSS “clearly recognized three levels of war and reflected several key elements of operational art in its instruction in campaign planning." 38 Perhaps most importantly, key individuals in the army understood that the CGSS curriculum must educate officers on the basics that they would rely upon to train and lead untrained draftees in the event of a mobilization for war. The AWC built upon the academic foundation of CGSS, but focused on service in large units as general staff officers or commanders, planning and executing campaigns using methods very much akin to those now known as operational art. ${ }^{39}$

The AWC curriculum and aim differed greatly from that of CGSS - the realm of strategy and the strategic level of war. From 1919 through most of the 1920s, the AWC curriculum focused on the operational and strategic level issues related to Connor's Preparation for War and Conduct of War, and what Major General James McAndrew referred to as the one Big Problem. ${ }^{40}$ Curriculum focused on history, personnel, intelligence, operations and training, logistics, mobilization, campaign planning, and war plans, all at the theater strategic and operational

\footnotetext{
${ }^{37}$ Nenninger, “Leavenworth and its Critics,” 203.

${ }^{38}$ Matheny, Carrying the War to the Enemy, 55.

${ }^{39}$ Ibid., 58, 88-90.

${ }^{40}$ Pappas, Prudens Futuri, 93-96; Robert E. Petty V, “Training vs. Education at the Army War College: The Benefits of a Return to the Past” (Monograph, Command and General Staff
} College, 2014), 28. 
levels. ${ }^{41}$ Additionally, the AWC curriculum included economic studies of supply and industry, as historian George Pappas put it, "with a view to securing cooperation and coordination of governmental and industrial agencies of the nation," in the event of war. ${ }^{42}$ Therefore, the AWC focused on the education and development of the future strategic and operational level commander and general staff officer. These are the officers who mobilized, led, and commanded formations, manned with e officers that understood operational art and its many requirements and functions.

Students at the AWC also served a functional purpose to the War Department. Along with the study of historical campaigns and operations, committees of students assisted the War Plans Department by reviewing actual war plans. Each class provided detailed input on the various war plans developed to deal with a "worst case” scenario against a range of possible enemies including Japan and even Great Britain. ${ }^{43}$ The scenarios, known as the colored war plans (later, the Rainbow Plans) included joint operational planning with students from the Naval War College. ${ }^{44}$ Therefore, beginning very early in the interwar period, senior officers of the Army and Navy began expanding their knowledge and experience in strategy development, campaign planning, and joint operations. ${ }^{45}$ As a result, these officers developed a detailed understanding of operational art and the command and staff duties of the operational level of war. These senior leaders' knowledge proved essential years later as the United States found itself drawn into yet another world war. After 1923, the AWC curriculum remained consistent in its use of real War

\footnotetext{
${ }^{41}$ Matheny, Carrying the War to the Enemy, 58-68; Petty, "Training vs. Education at the Army War College,” 27.

42 Pappas, Prudens Futuri, 90.

${ }^{43}$ Ball, Of Responsible Command, 155-58; Matheny, Carrying the War to the Enemy, 58; Petty, "Training vs. Education at the Army War College," 27-28.

${ }^{44}$ Petty, “Training vs. Education at the Army War College,” 27-28.

${ }^{45}$ Matheny, Carrying the War to the Enemy, 58.
} 
Department war plans, changing only in the scenarios it used in the curriculum as it reviewed war plans for dealing with threats from a wider array of possible enemies.

In 1934, the AWC built on the existing curriculum, to include developing plans for fighting conflicts in conjunction with Allies. ${ }^{46}$ These conflict scenarios involved nations (each assigned a color) as a part of a coalition with the United States, against a wide range of adversaries, individually and fighting as coalitions against the United States. ${ }^{47}$ Students, aware of the existing national security policy and most up to date intelligence, analyzed the situation and developed plans that included the conduct and objectives of the war, the extent of United States participation, as well as the extent of allied participation. ${ }^{48}$ According to Gole, this "was not an exercise limited to military operations.”49 Schifferle contended the AWC curriculum and its students served as nothing more than a "problem solving extension of the War Department." 50 However, the recommendations that the AWC students provided to the particular plans were simply that, recommendations. The War Department read each class' recommendations and if they found the recommendations useful, politically acceptable, and economically feasible, the War Plans division would modify policies or plans as needed. More often than not, the war plans division found the plans infeasible. Assisting in the development of the Rainbow Plans produced a level of understanding in the students as to the complexity of the environments and the reality of possible scenarios that the US Army was to face in future conflicts. Therefore, the experience

${ }^{46}$ Henry G. Gole, The Road to Rainbow: Army Planning for Global War, 1934-1940 (Annapolis, MD: Naval Institute Press, 2002), 39; Matheny, Carrying the War to the Enemy, 80; Petty, “Training vs. Education at the Army War College," 29-30.

${ }^{47}$ Gole, The Road to Rainbow, 39-40; Matheny, Carrying the War to the Enemy, 80.

${ }^{48}$ Gole, The Road to Rainbow, 39-40; Matheny, Carrying the War to the Enemy, 79-82.

${ }^{49}$ Gole, The Road to Rainbow, 39.

${ }^{50}$ Schifferle, America's School for War, 34. 
gained in the AWC further alludes to the wide array of planning capabilities and that US Army officers possessed in the application of operational art during World War II. ${ }^{51}$

Students at CGSS and AWC endured long hours and strict academic standards. The average student at CGSS experienced an eight and a half hour day, which balanced the amount of time spent in lectures, classroom instruction, conferences, map exercises, and tactical map problems. ${ }^{52}$ The CGSS tactical map problems “...had to be completed in a limited time and each

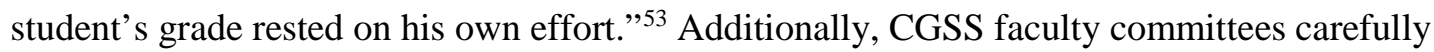
graded each student's solution to a problem, noting specific errors made in the solution, and finally provided a "school solution" to the problem to give students a means of comparison." 54 The AWC did not develop school solutions. The AWC emphasized the sharing of ideas through discussion, which allowed to students to form their own conclusions when solving problems at the operational and strategic levels. ${ }^{55}$ The school solution remains one of the major points of criticism in regards to the CGSS curriculum.

Historians such as Jörg Muth, Martin Blumenson, and Charles J. Kirkpatrick argued that the concept of the school solution, and the rigid problem solving methodology imparted on

${ }^{51}$ Ball, Of Responsible Command, 155-58; Petty, “Training vs. Education at the Army War College,” 25-34. Ball and Petty described how student led committees approached the problems they were presented with and the resulting recommendations provided to the War Department. Additionally, Petty's reference to the National Defense Act of 1920 further shows the limitations facing the War Department in accepting the AWC recommendations for war plan development.

52 U.S. Army Command and General Staff School, Annual Report(s) of the Command and General Staff School, 1919-1920 through 1939-1940 (Fort Leavenworth, KS: Command and General Staff School Press, 1920-1940); U.S. Army Command and General Staff School, Class Schedules for 1917-1917 through 1939-1940 (Fort Leavenworth, KS: Command and General Staff School Press, 1920-1940).

${ }^{53}$ Nenninger, “Leavenworth and its Critics,” 225.

${ }^{54}$ Ibid.

${ }^{55}$ Matheny, Carrying the War to the Enemy, 57. 
students at CGSS served as a hindrance to critical and creative thought. ${ }^{56}$ However, according to General Service Schools Memorandum No. 4, "In marking problems, the school solution should not be followed rigidly. Where the student shows a logical, reasonable, and sensible line of reasoning, he should receive full credit.”57 Therefore, students were not stifled critically and creatively; they adhered to a methodology that encouraged creative solutions to problems within an established theoretical and doctrinal framework. Critiques of CGSS and the AWC by notable graduates such as George S. Patton, Lawton Collins, Omar N. Bradley, and Dwight D.

Eisenhower vary greatly. However, it is clear that they valued the knowledge and experience gained from CGSS and AWC when immersed in the planning and decision-making of World War II. ${ }^{58}$

German Reichswehr and Kriegsakademie

\section{Background}

Inspired by the French Enlightenment and expanded by the military thinkers of the German Aufklärung in the 1770s, officer education in the German military has always remained paramount. ${ }^{59}$ The education established by the military thinkers of the Aufklärung, including that of Fredrick the Great, "reflected the belief that the art of war, like all arts, required professional education and considerable knowledge, and could be treated theoretically on the basis of rules

${ }^{56}$ Nenninger, “Leavenworth and its Critics,” 208; Muth, Command Culture, 131-32.

${ }^{57}$ General Service Schools, Memorandum No. 4, September 13, 1926 (Archives, Ike Skelton Combined Arms Research Library) accessed October 2, 2014.

${ }^{58}$ Nenninger, "Leavenworth and its Critics," 204-07. Nenninger provided the opinions, critiques, and relative value that these notable leaders placed in their "Leavenworth experience."

${ }^{59}$ Azar Gat, A History of Military Thought: From the Enlightenment to the Cold War (Oxford: Oxford University Press, 2001), 56-57. 
and principles that relied on historical evidence.” ${ }^{60}$ Although officer education evolved based on the influences of military thinkers, changes in theory, and a combination of various political, social, and economic factors; a general framework for officer education was established in Germany in the 1770s. From 1810 until Germany’s defeat in World War I, German military officers received formal military education from state and federal institutions in keeping with this mindset. ${ }^{61}$

The Treaty of Versailles nearly destroyed officer education in Germany. Specifically, Article 160 disbanded and outlawed the German General Staff, Article 175 made any theoretical and practical exercises illegal, and Article 176 disestablished the Kriegsakademie. ${ }^{62}$ Under the leadership of General William Groener (later Defense Minister) and General Hans von Seeckt (Commander in Chief of the German Army), officer education survived, renamed the German Reichswehr until 1935. Ultimately, Von Seeckt engendered a resurgence in the emphasis on the establishment of new doctrine and officer education in the German Army. ${ }^{63}$

\section{Narrative}

Although organized under the provisions of the Treaty of Versailles as the military organization of Germany, the Reichswehr from 1919-1935 served primarily as a school for officer

${ }^{60}$ Gat, A History of Military Thought, 59.

${ }^{61}$ Albert C. Wedemeyer, Report on the German General Staff School 1938 (Washington, DC: War Department, 1938). Prior to 1810, the responsibility of educating German officers resided on the state or province that the regiment was formed in. Wedemeyer's report is an evaluation of the German officer education system, written after his time spent as a student at the Kriegsakadamie It also provides useful insight to the belief and development of combined arms doctrine in the German military prior to World War II.

${ }^{62}$ Hacken and Plotke, "Peace Treaty of Versailles.”

${ }^{63}$ Robert M. Citino, The German Way of War: From the Thirty Years' War to the Third Reich (Lawrence: University of Kansas Press, 2005), 240-44. 
education. ${ }^{64}$ The "T4,” Army Training Section of the Truppenamt (Troop Office), a front for the outlawed General Staff, served as the managerial element for officer education within the Reichswehr. ${ }^{65}$ The training section directed curriculum development in accordance with Führung und Gefecht der verbundenen Waffen (Leadership and Battle of the Combined Arms doctrine). ${ }^{66}$ The Führung und Gefecht der verbundenen Waffen established the doctrinal foundation for officer education in the German Army during the interwar period.

Germany's defeat and the limitations imposed by the Treaty of Versailles serve as a counterintuitive function in providing the Reichswehr and Von Seeckt, with a unique opportunity; to start over with a clean doctrinal slate after World War I, supported by the resolve to avenge their defeat. Von Seeckt organized committees of veteran officers that produced reports, which, in Williamson Murray’s words, “rested on solid, realistic assessments on what had actually occurred, not on what generals might have believed to happen." ${ }^{67}$ The committee’s reports and Von Seeckt's personal observations resulted in a doctrine that rested on a belief in combined arms maneuver, offensive minded operations, decentralization of operations, officers’ and noncommissioned officers' use of judgment in battlefield decision-making, and the constant display of initiative. ${ }^{68}$ These doctrinal concepts not only influenced the publication of Führung und Gefecht der verbundenen Waffen, they also influenced a cultural shift within the Reichswehr that

${ }^{64}$ Citino, The Path to Blitzkrieg, 73; Muth, Command Culture, 149.

${ }^{65}$ Muth, Command Culture, 149.

${ }^{66}$ Citino, The German Way of War, 241-42; Citino, The Path to Blitzkrieg, 12-23. The Führung und Gefecht der verbundenen Waffen (Leadership and Battle of the Combined Arms doctrine) was first published in 1921 and revised in 1923. There were later versions of this publication, however these two versions serve as the doctrinal base for the restructuring of German professional military education during the interwar period.

${ }^{67}$ Williamson Murray, "Armored Warfare: The British, French, and German experiences,” in Military Innovation in the Interwar Period, ed. Williamson Murray and Allan R. Millett (New York: Cambridge University Press, 1996), 37.

${ }^{68}$ Ibid., 37-38; F.W. Wilburn, trans., Truppenführung, Part I (Special Collections, Ike Skelton Combined Arms Library, 1933). 
compelled officers at all levels to develop intimate familiarity with the new tactical doctrine. Unlike CGSS, the Reichswehr tested officer's knowledge in the aforementioned doctrine in the arduous Wehrkreis Prüfung (defense district exams). Recommendation letters, performance evaluations, and exam results provided an objective measure of each officer's qualifications to enter the General Staff Course. ${ }^{69}$

Similar in concept to CGSS, the General Staff Course was a four-year program that prepared officers in the ranks of first lieutenant and captain to serve on the general staff. The typical officer spent three years in academic course work and one year of practical experience with units before completing the course. ${ }^{70}$ Although an officer's district headquarters administered the first two years of the course, the T4's curriculum oversight ensured all unit instruction nested with current doctrine. In the first year of the course, students spent an average of twenty-two hours a week in classroom instruction with additional time spent on staff rides, war games, and map and tactical exercises. ${ }^{71}$

Similar to the School of the Line at CGSS, the curriculum of the first year school on combined arms maneuver tactics at the regimental level, including logistics, capabilities of all combat and supporting arms, air defense, and added classes on legal education, military history, physical fitness, and horsemanship. ${ }^{72}$ Additionally, the history classes centered on the tactical problem solving of historical battles. ${ }^{73}$ According to historian Robert Citino, the course focused

${ }^{69}$ David N. Spires, Image and Reality: The Making of the German Officer, 1921-1933 (Westport: Greenwood Press, 1984), 30-46.

${ }^{70}$ James S. Corum, The Roots of Blitzkrieg: Hans von Seeckt and German Military Reform (Lawrence: University Press of Kansas, 1992), 90.

${ }^{71}$ Ibid.; Citino, The Path to Blitzkrieg, 94-96.

${ }^{72}$ Citino, The Path to Blitzkrieg, 94-96; James A. Beaulieu, "The Education of MidCareer Officers: Building Competency through Professional Military Education” (Masters thesis, United States Military Academy at West Point, 2012), 4-5.

${ }^{73}$ Citino, The Path to Blitzkrieg, 97; Spires, Image and Reality, 42. 
more on tactical problems than on orders formulation and problems of logistics, thereby subordinating key functions of a general staff to those that belonged at the lower echelon headquarters: finding solutions to tactical problems. ${ }^{74}$ The second year course of the Division School followed a similar structure as the first year, with some minor differences.

Unlike the second year of CGSS, which centered on corps level operations, the second year of the general staff course focused on tactical operations at the division level. Officers received twenty-four hours of instruction in subject matter similar to the first year course. ${ }^{75}$ Additionally, students received instruction on the technique of command, chemical warfare, army organization, and army administration. ${ }^{76}$ Classes were tactics centric with limited classes on strategy. However, the classes on strategy that did occur were weak. Citino argued that this reflected the Germans’ focus “on the technical considerations, related to movement” as opposed to the "underlying political, economic, and psychological grounds by which war is waged."77 Citino's observation appears valid with respect to the first three years of the course, but his argument falters when applied to German officers' education during the fourth year of the course.

In the third year of the course, officers found themselves assigned to Reichswehr units to conduct "troop duty." During this period, an officer served as a "trainee” on infantry and cavalry division staffs. ${ }^{78}$ Based on an officer's performance at troop duty and the first two academic years, the officer then progressed to the highly selective fourth year of instruction at the

\footnotetext{
${ }^{74}$ Citino, The Path to Blitzkrieg, 97.

${ }^{75}$ Spires, Image and Reality, 42.

${ }^{76}$ Citino, The Path to Blitzkrieg, 95.

${ }^{77}$ Ibid., 99-100.

${ }^{78}$ Corum, The Roots of Blitzkrieg, 90-91.
} 
Reichswehr in Berlin. However, advancement to the fourth year was not guaranteed and often did not happen. ${ }^{79}$

In the fourth and final year of the program, curriculum switched to corps and army level operations and included, according to David Spires, "instruction on foreign armies and modern army-navy cooperation.” ${ }^{80}$ German officers also received lectures on political, economic, and international affairs, although the course itself remained practical and militarily centric in nature. ${ }^{81}$ Grading throughout the general staff course also mirrored the AWC. Students were required to write papers and solve problems however, instructors reviewed and discussed products in seminars to enable all officers to learn independently and form their own conclusions. ${ }^{82}$ This reinforced war's complex and unpredictable nature, as did the lack of a faculty-provided correct answer or "school solution.” While the Reichswehr formally instructed and evaluated officers through tactical and operational level curriculum, its curriculum and instruction only informally addressed strategy. ${ }^{83}$

This lack of formal strategic education resulted from the limitations imposed by the Treaty of Versailles, the emphasis placed on tactical and operational subjects within the Reichswehr, and the fact that the German Army isolated strategic education for only the senior leaders of the Reichswehr. The informal education took place through means such as Von Seeckt conducting staff rides that included analysis of combatant strategy and winter war games that included political and international strategic considerations. ${ }^{84}$ While the Reichswehr provided

\footnotetext{
${ }^{79}$ Corum, The Roots of Blitzkrieg, 92.

${ }^{80}$ Spires, Image and Reality, 41-46.

${ }^{81}$ Corum, The Roots of Blitzkrieg, 92.

82 James A. Beaulieu, “The Education of Mid-Career Officers," 4-5; Citino, The Path to
} Blitzkrieg, 91-92.

${ }^{83}$ Corum, The Roots of Blitzkrieg, 95-96.

${ }^{84}$ Ibid., 96. 
some instruction on strategy and the strategic level during the interwar period, the limitation of formal education on strategy to senior officers combined with the informal nature of such instruction at the Reichswehr resulted in an overall deficiency in strategic thinking amongst Wehrmacht officers during the interwar period. ${ }^{85}$ Therefore, with an educational focus that was tactically centric rather than balanced with strategy and the strategic level, only select senior leaders of the Reichswehr and the Wehrmacht possessed an understanding of operational art and theater strategy.

Academics in the General Staff Course, performance, experience, and the winter war games helped to identify the leaders within the Reichswehr and Wehrmacht that would develop future theater strategies. Additionally, it assisted in identifying the leaders that had the potential to command at the army and army group level. However, the overemphasis of tactics in these officers' education meant that they did not possess a sound grasp of national or theater strategy. Once Adolf Hitler removed the officers who could have served as key strategic leaders on the general staff, but did not demonstrate sufficient loyalty to him, he created a shortage of officers with both a solid grasp of strategic issues and a willingness to advocate sound German strategy that differed from Hitler's views as the events of the 1930s unfolded. ${ }^{86}$ As Hitler increasingly managed German war strategy and the German officer corps — with some exceptions—officers

${ }^{85}$ Corum, The Roots of Blitzkrieg, 95-96; Patrick J. Cassidy, “German Officer Strategic Education: A Critical Omission” (Masters thesis, US Army War College, 2002), 16-18.

${ }^{86}$ Corum, The Roots of Blitzkrieg, 96; Geoffrey P. Megargee, Inside Hitler's High Command (Lawrence: University Press of Kansas, 200), 28-44, 61-66; Gerhard L. Weinberg, Germany, Hitler \& World War II (Cambridge: Cambridge University Press, 1996), 132-38. Hitler's response to the Blomberg-Fritsch affair effectively stifled the German General Staff and led to the resignation of many officers who understood strategy and operational art. Such officers who remained in service and served in senior staff positions in the late 1930s remembered the fate of their predecessors, relieved or compelled to resign by Hitler, making them wary of risking the same fate by speaking up in opposition to Hitler’s strategic or military plans. 
did not resist his delusion-driven operational goals. ${ }^{87}$ As such, the advantages Germany developed in the conduct of tactical actions wasted away in the absence of strategic direction needed from the German officer corps to guide German operational art. ${ }^{88}$ This indicates that Von Seeckt and other key leaders within the Reichswehr and Wehrmacht created a highly effective officer education program for the execution of tactical actions. While Hitler's actions lacked rationality the grander his ambitions grew, his culling of the general staff simply brought the root problem to the surface. This system lacked the strengths of the American officer education system, which developed enough strategic leaders to overcome the US Army’s initial tactical inferiority and learn how to conduct operations in a way that made optimal use of the US Army's capabilities while minimizing the effect of its limitations.

Synthesis

The Interwar Period presented tough challenges for the US Army and the German Reichswehr. Both armies mitigated the effects of limited military funding and the political, social, and economic turmoil of the period by preparing for the next war through professional officer education. Both nations' military educational systems revealed their awareness of the benefit that their officer corps gained from mastery of combined arms doctrine, joint and combined multinational operations, the importance of logistics, critical and creative thinking in problem solving, common and shared understanding of what became known as operational art, campaign planning, and strategy (to various degrees). Additionally, both nations' officer education at the field grade level stressed the importance of technological innovation in land, air, and naval

\footnotetext{
${ }^{87}$ Megargee, Inside Hitler's High Command, 61-66; Weinberg, Germany, Hitler \& World War II, 138-44

${ }^{88}$ Megargee, Inside Hitler's High Command, 61-66; Weinberg, Germany, Hitler \& World War II, 138-44.
} 
power, although neither nation had the funding to develop these innovations in any significant way until the last several years of the interwar period.

CGSS created competent, professional, and dedicated officers at the tactical and operational levels, while the AWC did this at the operational and strategic levels. The CGSS curriculum emphasized coordination and cooperation between the branches of the Army, while the AWC focused on the same between the Army (including the Army Air Corps) and the Navy. ${ }^{89}$ Additionally, the AWC concentrated on strategy development and strategic level planning. Therefore, the curriculums of both CGSS and AWC introduced field grade officers at all levels to topics related to mobilizing and projecting combat power, and planning joint combined arms operations that supported and achieved an overarching national objective, known today as operational art. ${ }^{90}$

The Reichswehr curriculum covered similar theoretical and doctrinal topics, but with both different methods and different areas of emphasis than the Americans. The first three years of the German General Staff training course focused heavily on the tactical and operational levels, and only in the fourth year did the few officers selected to attend transition into the operational and strategic level instruction. Their education system made German officers some of the world's most educated at the tactical and operational levels of war. Strategy received less formal coverage, and remained mostly exclusive to select senior officers within the Reichswehr and Wehrmacht. When given a mission, officers at the tactical and operational level could plan and execute operations to achieve an objective. More often than not, however, Hitler's centralization of decision-making authority, coupled with the informality of German strategic education failed to create a logical strategy development process, as well as a shared understanding of strategy in

\footnotetext{
${ }^{89}$ Matheny, Carrying the War to the Enemy, 89-91.

${ }^{90}$ Ibid.
} 
relation to operational art within the Wehrmacht officer corps. ${ }^{91}$ Therefore, the Germans did not possess a thorough understanding of strategy and operational art.

Both nations ran selective and demanding military education programs. Due to the political, economic, and social conditions of the interwar period, academic performance carried weight when senior leaders made decisions regarding promotions and retention in both armies. This emphasis placed on education as a means for promotion and retention created a sense of professionalism, competence, and dedication to duty in both armies, but this also created a problem for the Germans. ${ }^{92}$ The German military culture was overly selective to the point that when mass mobilization occurred in the 1930s, the Wehrmacht found itself lacking adequately trained officers for the general staff. ${ }^{93}$ Promotions of junior and non-commissioned officers, as well as recalls of reserve officers attempted to fix this problem, but it could only do so in limited amounts. ${ }^{94}$ Therefore, while both nations ensured quality and professional education for their officers, the Americans found themselves in a better position to mobilize, plan, and fight an expansive world war than the Germans.

The American and German emphasis on interwar period officer professional education clearly support Holder and Murray’s assertion that, “investments in intellectual excellence can pay dividends in the next war." 95 The American and German effectiveness during Operations in North Africa and Western Europe after D-Day help to demonstrate the relative strengths and weaknesses of officer education of the United States and Germany during the interwar period.

${ }^{91}$ Cassidy, “German Officer Strategic Education: A Critical Omission,” 16-17.

${ }^{92}$ Schifferle, America's School for War, 35; Spires, Image and Reality, 99-120; Corum, The Roots of Blitzkrieg, 94.

${ }^{93}$ Corum, The Roots of Blitzkrieg, 95.

${ }^{94}$ Ibid.

${ }^{95}$ Lt. Gen. Leonard D. Holder Jr. and Williamson Murray, "Prospects for Military Education,” Joint Forces Quarterly, no. 18 (June 1998): 81-90, accessed December 24, 2014, http://www.dtic.mil/doctrine/jfq/jfq-18.pdf. 


\section{World War II: Officer Education's Test}

North Africa Campaign

\section{Background}

Before the execution of Operation Torch in November 1942, the Allied powers faced a grim strategic situation. ${ }^{96}$ To seek solutions to the challenges they faced, the Allies held various conferences, one of the earliest, the Arcadia Conference (December 1941 to January 1942), discussed the Allied strategy for the war. This conference, when coupled with the interactions of American and British political and military leaders throughout July 1942, determined that the Allies would take a "Europe First” strategy, executing a combined allied operation against German forces no later than 1943 in North Africa. ${ }^{97}$ Appointed commander of Allied operations in North Africa, beginning with an amphibious assault codenamed Operation Torch, General Dwight D. Eisenhower lead a team that included CGSS and AWC graduates; General's Thomas Handy, Alfred M. Guenther, Mark Clark, Lyman Lemnitzer, George Patton, Omar Bradley, Ernest Harmon, and Lloyd Fredendall. ${ }^{98}$ The Allied operations from Torch to the end of the fighting in Tunisia serve as the first test of the education received by these officers during the interwar period.

${ }^{96}$ For a detailed explanation of the Allied strategic situation before Operation Torch see Combat Studies Institute, Operation Torch, North Africa Campaign: Offensive, Deliberate Assault, Amphibious, 8 November 1942 (Fort Leavenworth, Kansas: Government Printing Office, 1984), 1-18; William B. Breuer, Operation Torch: The Allied Gamble to Invade North Africa (New York: St. Martin’s Press, 1985), ix-xv; Matheny, Carrying the War to the Enemy, 161.

${ }^{97}$ George Forty, The Desert War (Gloucestershire, UK: Sutton Publishing Limited, 2002), 151; Matheny, Carrying the War to the Enemy, 161-65.

98 These officers all graduated CGSS and AWC during the interwar period. With little operational training and experience, they had to rely on the education they received at these schools when developing plans to solve the complex problems they would face when executing Operation Torch and operations in North Africa. 
The strategic situation for Germany by November 1942 was comparatively better than the Allies. ${ }^{99}$ Germany, in conjunction with Italy and Vichy France, controlled the western portion of the European continent. In the East, German forces with the assistance of their Axis partners were driving Russian forces deeper into Russia and threatening the overall control of Leningrad and Stalingrad. However, the Axis situation in North Africa was indecisive. The Vichy French, with little help from Germany, controlled Morocco, Algeria, and Tunisia. British forces at El Alamein decidedly defeated the German Afrika Korps under the command of Field Marshal Erwin Rommel in late 1942. Because of the defeat, the Afrika Korps under the ineffective command and control of the Commando Supremo (Italian Army) began to retreat from Egypt towards Tunisia.

Although Rommel did not receive formal education through the Reichswehr or the Kriegsakademie during the interwar period, he was well versed in the doctrine that formed the curriculum base of German officer education. Rommel served as an instructor at the Dresden Infantry School and the War College at Potsdam. ${ }^{100}$ Additionally, Rommel wrote several manuals that were in concert with Führung und Gefecht der verbundenen Waffen (Command and Battle of the Combined Arms doctrine) and the officer education curriculum. ${ }^{101}$

${ }^{99}$ For a detailed explanation of the German strategic situation prior to Operation Torch see Steven J. Zaloga, and Michael Weply, Kasserine Pass, 1943: Rommel's Last Victory (Oxford: Osprey Publishing, 2005), 7-9; Combat Studies Institute and United States Army Command and General Staff College. Operation Torch, North Africa Campaign, 1-18; Breuer, Operation Torch, ix-Xv.

${ }^{100}$ Karl Hoffman, Commanders in Focus: Erwin Rommel (London: Brassey’s Publishing, 2004), 10-16; David Fraser, Knight's Cross: A Life of Field Marshal Erwin Rommel (New York: Harper Collins Publishers, 1995), 85-98.

${ }^{101}$ Fraser, Knight's Cross, 85-98. 


\section{Narrative}

In August 1942, Eisenhower received his strategic guidance for operations in North Africa from General Marshall. ${ }^{102}$ Marshall directed Eisenhower to gain control of North Africa from the Atlantic to the Red Sea, in coordination with British forces advancing from the east towards Tunisia while pursing Rommel’s Afrika Korps. ${ }^{103}$ Additionally, Marshall ordered Eisenhower to achieve this through combined allied landings in Morocco, Algeria, and Tunisia (ultimately, the Allies abandoned the Tunisia landing, invading only Morocco and Algeria and advancing into Tunisia by ground) in order to establish bases of operation for the eventual offensive and annihilation of Axis forces in North Africa. ${ }^{104}$

Eisenhower's combined and joint operational planning team included both American and British officers. Generals Alfred M. Gruenther and Mark Clark, (chief and deputy chief of plans), along with General Lyman Lemnitzer (G3) faced a number of planning quandaries. ${ }^{105}$ They needed to ensure that the Allied forces, which would depart from separate ports of debarkation and travel along separate lines of communication, arrived at the precise time to secure their designated landing sites, ideally unscathed by German and French forces, as well as potential interdiction by Spanish air and naval forces. ${ }^{106}$ They also needed to provide adequate sustainment for the force as the Allies advanced east along lines of communication that were constricted by

${ }^{102}$ Forty, The Desert War, 149-50; Matheny, Carrying the War to the Enemy, 163-64.

${ }^{103}$ Forty, The Desert War, 163; George F. Howe, Northwest Africa: Seizing the Initiative in the West, United States Army in World War II: The Mediterranean Theater of Operations, ed. Kent R. Greenfield, 2nd ed. (Washington, DC: Office of the Chief of Military History, 1978), 16. West, 16.

${ }^{104}$ Forty, The Desert War, 163; Howe, Northwest Africa: Seizing the Initiative in the

${ }^{105}$ Howe, Northwest Africa: Seizing the Initiative in the West, 25-31; Matheny, Carrying the War to the Enemy, 164-72. Howe and Matheny for explain the problems that the planning team faced in development of the plan for Operation Torch. Additionally, the named members of the planning team were CGSS and AWC graduates.

${ }^{106}$ Orr Kelly, Meeting the Fox: The Allied Invasion of North Africa, From Operation Torch to Kasserine Pass to Victory in Tunisia (New York: John Wiley \& Sons, 2002), 13-21. 
terrain and vulnerable to German air attack. ${ }^{107}$ Perhaps most importantly, at least during the initial phase of the campaign, they sought to mitigate the ability of the Vichy French Forces to affect the landings and the follow-on operations into Tunisia. ${ }^{108}$

The planning team accounted for these problems, although faced various hurdles and prepared several versions of the plan along the way. The final plan, published in October 1943, called for the simultaneous landings by Major General George S. Patton’s Western Task Force in Morocco, Lieutenant General Lloyd Fredendall’s Central Task Force in Oran, and Major General Charles Ryder’s mostly British Eastern Task Force in Algiers. ${ }^{109}$ The plan directed the Eastern Task Force with landing, consolidating under British Major General Kenneth Anderson, and immediately advancing towards Tunis; the central task force would land, secure lodgment, and begin advancing east, while the western task force secured a base of operations for the Allies in Morocco. ${ }^{110}$ Additionally, a battalion of the 82 nd Airborne had the mission to arrive early and use the benefit of surprise to secure the airfields and ports. ${ }^{111}$ US Army Rangers were to secure coastal defense batteries and hold them until the main landing forces arrived, thereby deterring any significant counterattack from the Vichy French. ${ }^{112}$

The aforementioned tactical objectives supported the operational objective of cutting off the German retreat to Tunis, thus enabling the strategic objective, an eventual German surrender

${ }^{107}$ Kelly, Meeting the Fox, 13-21.

${ }^{108}$ Howe, Northwest Africa: Seizing the Initiative in the West, 25-31.

${ }^{109}$ Omar Bradley, A Soldier's Story (New York: Henry Holt and Company, 1951), 24; Charles Whitting, Disaster at Kasserine: Ike and the 1st (US) Army in North Africa 1943, 2nd ed. (South Yorkshire: Leo Cooper, 2003), 28-30.

${ }^{110}$ For more on the details of the planning of Operation Torch see Charles Whiting, Disaster at Kasserine, 28-30; Howe, Northwest Africa: Seizing the Initiative in the West, 39-54.

${ }^{111}$ Rick Atkinson, An Army at Dawn: The War in North Africa, 1942-1943 (New York: Henry Holt and Company, 2002), 79-91; Matheny, Carrying the War to the Enemy, 171-72. $171-72$.

112 Rick Atkinson, An Army at Dawn, 79-91; Matheny, Carrying the War to the Enemy, 
and allied control of North Africa. As described in the US Army’s official history, the plan listed "the objective, political considerations, and the missions of each task force, as well as aviation and naval support." ${ }^{113}$ In addressing these key considerations, the Allies confronted the problem holistically and drew upon the lessons learned while working on the Rainbow Plans at the AWC. The execution of the Allied landings and the follow-on operations to Tunis continued to test the strength of the interwar period officer education.

On November 8, 1942, the British and American Allies executed their first major operation of World War II. At the landing sites of all three task forces, the Allies experienced tactical delays. These resulted largely from Allies' limited experience in conducting airborne operations and major amphibious landings, and to a lesser degree, from patches of resistance by Vichy French forces. For example, at the Port of Fedala, allied ships were not configured effectively to support a timed, phased, and deliberate landing of combat power, and as such, operations were temporarily slowed. ${ }^{114}$ However, considering this was the first time the Allies attempted an amphibious landing of this magnitude it went surprisingly well. The flexibility of the plan and the versatility of commanders such as, Patton, Fredendall, Ryder, and Alexander allowed for adjustments that led to the landings achieving success by November 11, 1942 .

German intelligence reports anticipated the Allied invasion of North Africa. ${ }^{115}$ However, Axis forces did not begin to respond until after Allies established lodgments and began racing towards Tunis. Once they did respond, Axis forces delayed the Allies' movement to Tunis, benefiting from a greater concentration of forces, better air cover, and shorter lines of communication than those of the Allies (Axis forces operated much nearer to Tunis than the

\footnotetext{
${ }^{113}$ Howe, Northwest Africa: Seizing the Initiative in the West, 16-31; Matheny, Carrying the War to the Enemy, 171.

${ }^{114}$ Howe, Northwest Africa: Seizing the Initiative in the West, 139-41.

115 Ibid., 185-86.
} 
Allies' lines to Morocco). ${ }^{116}$ The actions of Allied commanders in adjusting the tactical plan for Torch, while still supporting the achievement of the overarching strategic objectives, indicates that interwar education instituted a clear understanding of operational art in American officers. Additionally, the rapid Axis response to Allied operations in North Africa did delay the Allied race to Tunis and allowed for the establishment of a strong defense in the port city before the Allies could mount a deliberate attack. However, the Axis forces' inability to exploit this success and maintain control of North Africa displays a lack of understanding of operational art. With the landings and lodgment consolidated, Operation Torch was complete and the transition to the North Africa campaign began.

From November 1942 through early January 1943, the British V Corps under Alexander and the US II Corps under Fredendall secured objectives that achieved limited operational success. ${ }^{117}$ The Allies experienced various setbacks however, that put their strategic aim at risk. Overextended lines of communication, limited allied close air support (mostly committed to strategic bombing and interdiction of German supply lines), bad weather, and a rapid and determined Axis response prevented the Allies from defeating Axis forces and securing Tunis as quickly as they hoped. In light of this, Eisenhower made the decision to take an operational pause, reconstitute, adjust the plan, and thereby avoiding an early culmination of operations. ${ }^{118}$ Eisenhower’s decision provided Rommel the opportunity to counterattack on February 14-15,

${ }^{116}$ Carlo D' Este, World War II in the Mediterranean (Chapel Hill: Algonquin Books of Chapel Hill, 1990), 7-10; Howe, Northwest Africa: Seizing the Initiative in the West, 310; Gerhard Weinberg, A World at Arms: A Global History of World War II (New York: Cambridge University Press, 1994), 435.

${ }^{117}$ Matheny, Carrying the War to the Enemy, 174-75. The initial Allied race to Tunis failed. Anderson's British V Corps was able to secure Bizerte and Tebourba, only 20 miles from Tunis by the end of November 1942. However, the Germans retook Tebourba and captured over a thousand prisoners on December 1, 1942. The British and American' did attempt one more push for Tunis on December 24. Ultimately, Rommel stopped the breakout and the Allies went into an operational pause in order to reconstitute for future operations.

${ }^{118}$ Ibid., 174. 
attacking northward while General Hans-Jürgen von Arnim, with whom Rommel refused to cooperate, would lead his Fifth Panzer Army against American and French forces defending further to the north, hoping to bloody and possibly rout the inexperienced Americans. Kesselring allowed these operations to take place separately rather than overruling his subordinates and forcing them to cooperate, in keeping with longstanding German tradition reflected in the glamorized term Auftragstaktik. ${ }^{119}$ Rommel's forces achieved relatively easy tactical victories in battles at Faïd Pass and Sidi Bou Zid, embarrassing the Americans and exposing their lack of experience. $^{120}$

With these tactical victories, Rommel pressed on with the attack, despite the wishes of Commando Supremo, initially securing the Kasserine Pass on February 20, 1943. By this time, however, the Americans had shaken off the initial shock of their first days in combat, and with the guidance of a few experienced leaders, they formed an integrated, combined arms defense-indepth at the rear of the Pass. ${ }^{121}$ This took place because of the initiative of Major General Terry Allen (1st Infantry Division) and Brigadier General Paul Robinett (Combat Command B, 1st Armored Division), and their understanding of the relationship between the tactical situation and achievement of the strategic objectives. ${ }^{122}$ The Allied defense-in-depth, skillfully employing all elements of the combined arms team, first stalled Rommel's attack and then caused it to stagnate,

${ }^{119}$ Howe, Northwest Africa: Seizing the Initiative in the West, 410; Matheny, Carrying the War to the Enemy, 174; Carlo D’Este, Eisenhower: A Soldier's Life (New York: Henry Holt, 2002), 391.

${ }^{120}$ Howe, Northwest Africa: Seizing the Initiative in the West, 410-22. The Axis planned to counterattack the Allies long before the operational pause taken by Eisenhower and Alexander. The Allies understood that an attack was coming, but not when, or from where. When the attack came, the Allies, initially caught off guard, had to conduct a delaying action to begin the arrangement of a defense-in-depth to stop the advance of Rommel's forces.

${ }^{121}$ Ibid., 457-58.

122 Ibid., 457-76. Howe provided a detailed account of how the American’s defense in depth turned the tide of Kasserine Pass and set the conditions for the return to the offensive. 
leading him to withdraw towards Tunis on February $23 .{ }^{123}$ The American actions in turning the tide of the campaign at Kasserine Pass led Gerhard Weinberg to recognize the remarkable ability of US Army personnel to learn and translate that learning quickly into success on the battlefield. ${ }^{124}$ Particularly in the case of American commanders, this vital ability originated in the education they received at CGSS and the AWC during the interwar period.

By contrast, the inability of Axis forces to even get along well enough to coordinate their operations highlights the weakness resulting from the independence and maverick behavior encouraged by their military traditions and education, distilled into the romanticized term Auftragstaktik. Upon Rommel's inability to translate his initial tactical success into a strategic victory, Eisenhower took the initiative to save the campaign. Eisenhower directed Fredendall to relieve Major General Orlando Ward and place Major General Ernest Harmon in command of First Armored Division in the capacity of deputy corps commander on February 22. ${ }^{125}$ Eisenhower then relieved Fredendall and replaced him with Major General George S. Patton on March 3. ${ }^{126}$ Additionally, Eisenhower streamlined the overall allied command structure, and

${ }^{123}$ Howe, Northwest Africa: Seizing the Initiative in the West, 457-58, 459-74; Atkinson, An Army at Dawn, 388-89. Allen and Robinett's units worked through the night of February 21, 1943 in preparing defensive-in-depth. With an umbrella of direct support Artillery, the commanders wove a defensive position that interlaced infantry with anti-tank guns, as well as tank support protected by natural defilade. When the Germans entered the anticipated avenues of approach on February 21, 1943, the forward observers were able to mass fires in coordination with the fires of maneuver units in both divisions. The defense proved to be extremely effective and as a result, Rommel was forced to retreat.

${ }^{124}$ Weinberg, A World at Arms, 443-44.

${ }^{125}$ Howe, Northwest Africa: Seizing the Initiative in the West, 471-73; Atkinson, An Army at Dawn, 388. The decision to replace Ward was based on his less than stellar performance at Sidi Bou Zid and Faïd Pass. Although Ward was still technically in command, Harmon took over operational responsibilities of the First Armored Division beginning on February 22, 1943.

${ }^{126}$ Breuer, Operation Torch, 68-80; Howe, Northwest Africa: Seizing the Initiative in the West, 487. The decision to relieve Fredendall in the aftermath of Kasserine Pass resulted from his poor operational decisions, the constant tension between him and subordinate commanders, as well as his ineffectiveness at maintaining the morale and fighting spirit of US troops under his command. Eisenhower understood that assigning Patton to relieve Fredendall offered the best 
rushed supplies and reinforcements to the frontlines. ${ }^{127}$ Therefore, Eisenhower's quick thinking coupled with the aggressive action of Alexander, Montgomery, and later Patton enabled an Allied return to the offensive at the operational level within only a few weeks of the Kasserine Pass battles. Additionally, despite the tactical and operational setbacks of February 1943, US Army leaders never lost sight of the strategic aim-control of North Africa, which draws direct linkage to the curriculum of American interwar officer education. After Kasserine Pass, the Allied offensive never stagnated, and by May 1943, the Allies controlled North Africa. ${ }^{128}$

The American success in Operation Torch and the North Africa Campaign is a testament to the benefits of America's interwar officer education. The US Army experienced setbacks throughout the campaign, particularly during the Kasserine Pass battles, which could have led to the collapse of the US II Corps and the encirclement from the southwest of the Allied forces in Tunisia. However, officer education prepared the inexperienced American combat leaders to face the complex problems of the North Africa campaign through the application of sound doctrine that facilitated an approach much like that described by the modern concept of operational art. This understanding enabled commanders to think about the bigger picture as they aligned their tactical actions in support of the achievement of Allied strategic objectives. US Army commanders learned from their mistakes, recovering from the exaggerated effect of the initial tactical defeats during the Kasserine Pass campaign to ultimately achieve success, stopping Rommel through skillful execution of a combined arms defense in depth that, as Weinberg pointed out, the British had not learned to do in three years of war against the Germans. ${ }^{129}$ The

chance of reinvigorating the American II Corps so it could carry out the remainder of the campaign.

${ }^{127}$ Matheny, Carrying the War to the Enemy, 175.

${ }^{128}$ Breuer, Operation Torch, 68-80.

${ }^{129}$ Atkinson, An Army at Dawn, 377; Weinberg, A World at Arms, 443-44. 
German Army continued to achieve tactical successes, however because of their educational focus at the tactical level they were never able to translate them into operational strategic victories. Operation Torch represents the beginning of a downward trend that by Operation Cobra clearly displayed the strengths of US Army officer interwar education and the weaknesses of Germany's.

Breakout from Normandy

\section{Background}

The Allies debated the timing of Operation Overlord, the Allied invasion of France, since America's entrance into World War II. ${ }^{130}$ Operation Overlord represented the culmination of three years of learning like that illustrated in the analysis of operations in North Africa. It also represented the culmination of three years of intensive planning that began with Eisenhower's draft Operation Bolero, later Operation Roundup, and after much debate over the Chief of Staff Supreme Allied Commander (COSSAC) documents, finally became Operation Overlord. ${ }^{131}$ On D-Day, June 6, 1944, the Allies executed operation Overlord, shifting the balance of the war significantly in the favor of the Allies.

With the exception of Caen, the Allies were able to seize and retain most of the initial objectives indicated in the Overlord Plan. However, twenty-five days after the initial landings $(\mathrm{D}+25)$, the Allies made little progress towards their intermediate objective, phase line yellow (the point from which the Allies anticipated the speeding up of operations as their forces turned

${ }^{130}$ Matheny, Carrying the War to the Enemy, 184-85.

${ }^{131}$ For a detailed explanation and the factors involved in the planning for Operation Overlord see Michael R. Matheny, Carrying the War to the Enemy, 184-201; Digest of Operation Overlord, Chief of Staff of the Supreme Allied Commander Allied Forces, G-3 Operations Plan Overlord, July 7, 1943, accessed December 23, 2014, http://cgsc.contentdm.oclc.org/cdm/ref /collection/p4013coll8/id/1246 
east to continue the attack towards Germany). ${ }^{132}$ In the development of the Overlord Plan, Allied planners underestimated the constricting Normandy terrain, specifically the hedgerows, which created the major delay in the allied advance from the Normandy beachhead. ${ }^{133}$ The destruction of the Cherbourg port by the Germans and one (the American) of the two mulberry ports by a storm on June 19 worsened the delay. ${ }^{134}$ The resulting late buildup of Allied manpower and supplies, as well as the stiff German resistance in the constricting hedgerow country, began to worry Bradley. ${ }^{135}$

Generals Eisenhower, Montgomery, and Bradley understood that a breakout was necessary to maintain the initiative and expand operations along the broad front desired in the Overlord plan. The question facing the Allies centered on when, where, and with what capability was the breakout to occur. ${ }^{136}$ As such, planning for Operation Goodwood and Operation Cobra, the combined allied breakout from the Normandy beachhead began in early July $1944 .{ }^{137}$

${ }^{132}$ Martin Blumenson, European Theater of Operations: Breakout and Pursuit, United States Army in World War II, ed. Kent R. Greenfield (Washington, DC: Office of the Chief of Military History, 1961), 3-4, 185; John Prados, Normandy Crucible: The Decisive Battle that Shaped World War II and Europe (New York: New American Library, 2011), 2-3.

${ }^{133}$ Michael E. Doubler, Closing with the Enemy: How the GIs fought the War in Europe, 1944-1945 (Lawrence: University Press of Kansas, 1994), 61; Russell F. Weigley, "Normandy to Falaise: A Critique of Allied Operational Planning in 1944,” 393-97.

${ }^{134}$ Guy Hartcup, Code Name Mulberry: The Planning, Building and Operations of the Normandy Harbours (New York: Hippocrene Books, 1977), 108-22; Alfred Stanford, Force Mulberry: The Planning and Installation of the Artificial Harbor off U.S. Normandy Beaches in World War II (New York: William and Morrow Company, 1951), 8-9.

${ }^{135}$ Prados, Normandy Crucible, 4.

${ }^{136}$ For a through explanation of the factors and the decisions made regarding Cobra and the overall breakout from the Normandy beachhead see Blumenson, Breakout and Pursuit, 18588.

${ }^{137}$ Ibid., 37; Steven J. Zaloga and Tony Bryan, Operation Cobra: Breakout from Normandy (Oxford: Osprey Publishing, 2001), 10. 


\section{Narrative}

Following an operations meeting with General Bernard Montgomery at Supreme Headquarters, Allied Expeditionary Forces (SHAEF), Bradley consulted his staff and began the planning for Operation Cobra on July 10, 1944, while Montgomery began planning for Operation Goodwood on July 14. ${ }^{138}$ The Cobra plan, which took Bradley and General Lawton Collins two days to develop conceptually, rested on two key assumptions: the effectiveness of a preparatory aerial bombardment, and a limited availability of German reserves positioned to counterattack at the point of an American breach. ${ }^{139}$ The operational goals of the plan included breaking the Normandy stalemate, securing the ports in Brittany in order to allow further buildup of manpower and supplies, and ultimately achieving the conditions necessary to begin open maneuver warfare. ${ }^{140}$ Additionally, the plan supported the overarching strategic objective of securing Paris and the setting of conditions for the eventual drive into Germany. The aforementioned layers of the Cobra plan, when coupled with the operational experience of the American leaders further indicates the effectiveness of interwar education in implementing the concept of operational art.

The Cobra plan carried a high degree of risk. As noted by leaders within the Allied Expeditionary Air Forces, the proximity of the troops to the proposed target area and the corresponding flight paths of Allied aircraft presented the potential for large numbers of friendly air and ground casualties. ${ }^{141}$ However, when Bradley left a July 19 planning conference with the Allied Air Forces in England, he was under the impression that the bombers would follow a flight

\footnotetext{
138 Blumenson, Breakout and Pursuit, 186-87; Prados, Normandy Crucible, 4.

139 Blumenson, Breakout and Pursuit, 187-88.

${ }^{140}$ Ibid., 197-98; James J. Carafano, After D-Day: Operation Cobra and the Normandy Breakout (Boulder, CO: Lynne Rienner Publishers, 2000), 73-74.
}

${ }^{141}$ Prados, Normandy Crucible, 9-12. 
path parallel to the forward line of troops. ${ }^{142}$ When the Allies executed Cobra, this would not be the case.

Released on July 13, and further refined by Lieutenant General Collins before execution, the plan for Operation Cobra included considerations necessary for its coordination with Montgomery's own breakout effort, Operation Goodwood, which was the Allied main effort. ${ }^{143}$ The first part of Cobra consisted of an aerial bombardment and artillery barrage in a penetration zone seven thousand yards wide by twenty-five hundred feet deep between Marigny and SaintGilles. Once the barrage weakened the German Forces enough to allow a ground assault, a penetration force from Collins' VII Corps consisting of three infantry divisions was to create a breach in the German lines west of St. Lo. An exploitation force consisting of three mechanized divisions would then expand the breach, opening the door to exploitation along a broad offensive frontage towards Constances and, ultimately, Germany. ${ }^{144}$ Initially intended to take place simultaneously with Operation Goodwood on July 18, Allied planners amended Cobra to take place three days after Goodwood on July 21. This was due in part to the slow American advance

${ }^{142}$ Doubler, Closing with the Enemy, 68-79; Prados, Normandy Crucible, 9-12; Blumenson, Breakout and Pursuit, 232-33.

${ }^{143}$ See Blumenson, Breakout and Pursuit, 218-19; Martin Blumenson, The Battle of the Generals: The Untold Story of the Falaise Pocket - The Campaign that should have Won World War II (New York: Morrow Publishing, 1993), 131; Carafano, After D-Day, 85-92 for a detailed explanation of Lieutenant General Lawton Collins' change of the initial Cobra Plan. Several historians, as noted throughout, have agreed with Bradley's assessment that Collins' adjustments significantly improved the success of the Cobra plan.

${ }^{144}$ Michael E. Doubler, Closing with the Enemy, 57; Cir, HQ, "First U.S. Army, Outline Plan: Operation Cobra," and attachments National Archives and Research Administration II (NARA II), College Park, MD, RG 407, box 1974, WWII Ops Reports, 101-3.5, G-3 Operation Plan Cobra $1^{\text {st }}$ Army, July 1944; Russell F. Weigley, "Normandy to Falaise: A Critique of Allied Operational Planning in 1944,” 403. 
in the Cotentin Peninsula, the turbulent weather in Normandy, and the prioritization of resources in support of Operation Goodwood. ${ }^{145}$

The Allied plan intended Operation Goodwood, the main effort, to expand the lodgment in the British sector and finally achieve the long-elusive breakout near Caen. Promising Eisenhower a decisive victory, Montgomery massed two British and one Canadian corps with heavy tactical air support against five German divisions. ${ }^{146}$ The British forces, mostly composed of armored divisions under General Richard Nugent O’Connor's VII Corps were to secure the Bourguébus Ridge between Bretteville-sur-Laize and Vimont and destroy as much of the defending German armored forces as possible. ${ }^{147}$ Simultaneously, the Canadian II Corps under Lieutenant General Guy Granville Simonds was to execute Operation Atlantic, an attack from the center of Caen towards the south in order to secure the remaining German-occupied sections of city. ${ }^{148}$

Despite allied bombing and the rolling artillery barrage, the slow advance of the British met a stiff and integrated defense-in-depth under the command of General Heinrich Eberbach and Panzer Group West from the onset. ${ }^{149}$ Excessive cratering of the battlefield from the allied bombing and rolling artillery barrage, made the initial waves of armored penetration forces, in an

145 Blumenson, Breakout and Pursuit, 189. Operation Cobra, although amended to be executed on July 21, 1944, actually began on July 25, 1944 after the aborted attempt on July 24.

${ }^{146}$ For background on the British use of armor during Operation Goodwood see: Ibid., 188-90; Max Hastings, Overlord: D-Day and the Battle for Normandy (New York: Simon and Schuster, 1984), 230; Atkinson, The Guns at Last Light: The War in Western Europe, 1944-1945 (New York: Henry Holt and Company, 2013), 133.

${ }^{147}$ Hastings, Overlord: D-Day and the Battle for Normandy, 230-31.

${ }_{148}$ Blumenson, Breakout and Pursuit, 189; Hastings, Overlord: D-Day and the Battle for Normandy, 230-31.

149 Thomas Alexander Hughes, Overlord: General Pete Quesada and the Triumph of Tactical Air Power in World War II (New York: The Free Press, 1995), 194-97. 
already constricted terrain, difficult if not impossible to execute. ${ }^{150}$ The cratering, in addition to the German knowledge of the operation, the lack of ad-hoc close air support and unobserved artillery fire allowed the Germans resistance to stifle any British attempt at a breakout. ${ }^{151}$ Goodwood culminated on July 20, 1944 without achieving its intended objectives. Goodwood did not enable the allied breakout that Montgomery and SHAEF had hoped for, but it did secure Caen, thirty-four additional square miles of French territory, it enlarged the beachhead enabling the further buildup of forces in the British sector, and it tied up German forces that could have been otherwise used against Cobra. ${ }^{152}$ However, the failure of the British to achieve success in Goodwood further supports Weinberg's point that the US Army learned much faster than its Commonwealth partners during operations in Tunisia in 1943. During Goodwood, Commonwealth forces used nearly identical methods and experienced many of the same challenges they faced in previous attempts to break out from Caen. Operation Cobra would indicate whether US Army interwar education provided the means for officers to continue to learn and adapt their doctrinal based plans as situations evolved, enabling them to achieve success where their Commonwealth Allies led by Montgomery had not. With the limited operational success of Operation Goodwood, the allied breakout from Normandy rested on the success of Operation Cobra.

Operation Cobra began with a series of operational setbacks on July 24, 1944. The turbulent weather that affected the Normandy coast compelled Bradley and Collins to postpone

${ }^{150}$ Blumenson, Breakout and Pursuit, 189-93; Robert Neillands, The Battle of Normandy, 1944 (New York: Sterling Publishing, 2002), 255. Montgomery in the planning for Operation Goodwood, attempted to avoid the cratering caused by high-explosive munitions that had previously stifled earlier British attempts to take Caen. He elected for using fragmentation munitions, however, there were large amounts of cratering effects that inhibited the British attack from the beginning.

${ }^{151}$ Neillands, The Battle of Normandy, 258-68; Hughes, Overlord, 196.

152 Atkinson, The Guns at Last Light, 137; Blumenson, Breakout and Pursuit, 193-94; Neillands, The Battle of Normandy, 265. 
the operation by twenty-four hours. However, word of the postponement did not reach Allied Air Command until the bombers had already taken off. A recall was initiated, but it was too late to stop all of them. The remaining bombers approached the target area along a perpendicular path, not the parallel approach that Bradley believed the Allies had settled upon. ${ }^{153}$ The first bombers created huge clouds of dust that obscured vision thereafter, contributing to significant American losses caused by inaccurate bomb drops totaling 25 Americans killed and 131 wounded. This tragedy occurred again the next day, July 25, at much larger scale, with 111 killed and over 490 wounded, including a key figure of US interwar officer education, Lieutenant General Lesley J. McNair. ${ }^{154}$ Despite the planning and coordination failure, as well as the losses during the preparatory bombing, the Operation Cobra commenced on July 25, initially achieving only slow, tactical gains.

By the afternoon of July 25, VII Corps had only made limited progress and the potential success of the operation was in question. Collins, who intimately understood the operational objectives, determined that the lack of a German counterattack as indication of favorable conditions for the commitment of the exploitation force the next day. ${ }^{155}$ Using the initiative that Cobra allowed for, Collins’ VII corps and the supporting VIII Corps under Major General Troy Middleton smashed through the breach the morning of July 26. The supporting XIX corps under Major General Charles Corlett blocked numerous attempts by the German Seventh Army to seal the American breach. ${ }^{156}$ Additionally, Eisenhower's decision in March 1944 to shift the strategic bombing targets from German infrastructure to key German transportation lines of

${ }^{153}$ Blumenson, Breakout and Pursuit, 228-29; Carlo D’Este, Decision in Normandy, 2nd ed. (New York: Harper Perennial Publishing, 1991), 400-03.

${ }^{154}$ Doubler, Closing with the Enemy, 79-81; D’Este, Decision in Normandy, 401-02; Blumenson, Breakout and Pursuit, 234-36.

${ }^{155}$ Atkinson, The Guns at Last Light, 145-46; Blumenson, Breakout and Pursuit, 246.

${ }^{156}$ Atkinson, The Guns at Last Light, 145-46. 
communication and the Luftwaffe severely hindered the German ability to resupply manpower and resources, as well as provide close air support in the wake of both Overlord and Cobra. ${ }^{157}$ As a result, by the evening of July 26 the Americans had secured St. Giles and Marigny, leaving the Germans in complete disarray.

From the morning of July 27 through July 29, 1944, Cobra achieved significant success. Collins and Middleton advanced towards the Cotentin coast as combined arms fires from armor, artillery, and the air corps inflicted significant losses on the German forces. The Germans did, however, manage to conduct limited counterattacks that allowed a significant amount of German personnel and equipment to escape entrapment in Cotentin. ${ }^{158}$ Regardless, Countances fell to the Americans on July 29, 1944. On July 30, the Fourth Infantry Division of Collins’ VII Corps secured an undefended Avranches. Once again, the Germans counterattacked, but American combined arms fires quickly defeated German forces. The defeat of the German counterattack at Avranches and the ensuing German retreat revealed that Cobra was an operational and strategic success. The Americans achieved their desired operational objectives and the conditions for the pursuit of the Allied strategic objectives were continuing to solidify. In contrast, the German counterattacks served as nothing more than a brief tactical gamble for an army that focused on tactical considerations rather than operational art, in keeping with the education German officers had received before the war. The American success during Operation Cobra, coupled with the ensuing British breakout set the conditions for the ensuing envelopment and capture of fifty thousand German soldiers in the Falaise-Argentan Pocket on August 19, $1944 .{ }^{159}$

${ }^{157}$ Alan Wilt, “The Air Campaign” in D-Day, 1944, ed. Theodore A. Wilson, 2nd ed. (Lawrence: University Press of Kansas, 1994), 139-54; William R. Betson, “Centers of Gravity, Lines of Operations, and the Normandy Campaign” (master's thesis, U.S. Command and General Staff College, 1987), 12-13.

${ }^{158}$ Atkinson, The Guns at Last Light, 146-47; Blumenson, Breakout and Pursuit, 271-72.

${ }^{159}$ D’Este, Decision in Normandy, 430-31. 
According to Russell Weigley, the American inability to foresee and fully exploit this tactical success of Operation Cobra by closing the Falaise-Argentan Pocket and encircling a much larger German Force demonstrated a lack of understanding of operational art. ${ }^{160}$ No commander or operational artist can foresee and account for the events that the fog and friction of war produce. ${ }^{161}$ The Cobra plan was adaptive, flexible, and an allowed for emergent strategy as seen in the initiative of commanders such as Bradley, Collins, Middleton, Corlett, and Patton to make the decisions that allowed for the formation of the Falaise-Argentan Pocket in the first place. Furthermore, this emergent strategy had linkages between the objectives at all levels of war and the operational commanders clearly understood them. Finally, closing the pocket would have led to dangerously thin American lines, and Bradley chose not to accept this risk. Only an overly critical view can explain the decades of criticism historians have aimed at the actions around the Falaise-Argentan Pocket, where the escape of some German forces amounted to a tactical disappointment at worst, and very insignificant when considered within the larger context of the highly successful Operation Cobra. This further supports the view that the training and education of the interwar period instituted an understanding of operational art, which in July, 1944 facilitated the success of Operation Cobra, as well as the transition to combined arms maneuver warfare, which was the basis of US Army doctrine throughout the interwar period. ${ }^{162}$

Synthesis

Operations in North Africa and the breakout during Operation Cobra presented officers of the American and German armies with tough challenges. Each campaign represented a complex

${ }^{160}$ Weigley, “Normandy to Falaise,” 401-10.

${ }^{161}$ Carl von Clausewitz, On War, trans. and ed. Michael Howard and Peter Paret (Princeton: Princeton University Press, 1989), 119-21.

162 Carafano, After D-Day, 265. 
situation. American officers at the strategic and operational level possessed limited, if any experience to help them cope with the associated challenges. Therefore, American officers had to turn to their interwar education in order to solve the problems they faced. Their German counterparts possessed, in many cases, experience with operations of similar scale, but this experience only reinforced their interwar education based on longstanding German tradition. These historical cases, evaluated using three elements of operational art (center of gravity, phasing and transitions, and risk) highlight key characteristics of interwar period officer education that contributed to each nation's understanding of operational art. ${ }^{163}$

In the planning for Operation Torch and its follow-on operations, American and Allied planners sought the strategic objective of gaining control of North Africa. ${ }^{164}$ Eisenhower and his planners understood, once the gamble of the race for Tunis failed to pay off, that in order to achieve the strategic objective the Allies had to defeat the Axis operational center of gravity, Rommel's Afrika Korps, the elite Axis unit with years of experience fighting in the desert, and led by one of the war's most famous officers. The Allies accomplished this by developing a phased plan that allowed for the transition from the initial landings and buildup of combat power, through a series of tactical actions in southern and eastern Tunisia leading to the final assault and victory at Tunis. Despite the tactical defeats at Sidi Bou Zid and Faïd Pass as well as the setback of Kasserine Pass, Eisenhower and his planners mitigated risk through effective combined operational planning, a unified command structure, protected sea and ground lines of communication, and maneuver centric combined-arms warfare. Operation Torch revealed flaws in numerous areas. However, as Allied operations progressed over the coming months, the American forces and commanders from Eisenhower down to tactical echelons displayed a clear

\footnotetext{
163 ADRP 3-0, 4-1- 4-9.

${ }^{164}$ George Forty, The Desert War, 149-50.
} 
understanding of the linkage between tactical actions and strategic objectives within the unifying structure of an integrated and well-supported campaign. ${ }^{165}$ This understanding of operational art among American forces experiencing combat in most cases for the first time, traces back directly to the education US Army officers received during the interwar period. However, operations in North Africa meant more to the Americans than simply achieving strategic objectives.

Upon America’s entrance into World War II, the US Army’s senior leaders focused on a direct campaign of mass and concentration intended to defeated Axis powers on the continent of Europe quickly, not on an indirect strategy initiated in North Africa. ${ }^{166}$ This mentality and culture within the army changed based on a number of strategic factors. ${ }^{167}$ The corresponding change in strategy and culture ultimately provided a unique opportunity for American officers. In 1942, the recently mobilized and expanded US Army had an established doctrine that was evaluated and tested, but the personnel responsible for its employment lacked experience at all levels of war. The North Africa campaign not only provided these personnel with tactical experience against Germany, it also gave the graduates of CGSS and the AWC an opportunity to test their interwar education at all levels and continue to learn, while facing the Germans in combat for the first time in the Second World War, and winning. Furthermore, the experience gained by American officers, when coupled with the battle hardening of the American combat solider, helped the US Army develop into a tough opponent for the Germans as the war progressed.

The German strategic objectives in response to Allied operations in North Africa consisted of two parts. The first involved maintaining Axis control of North Africa in an effort to

\footnotetext{
165 Matheny, Carrying the War to the Enemy, 184.

${ }^{166}$ Atkinson, An Army at Dawn, 11.

${ }^{167}$ For a detailed explanation of the strategic factors that contributed to the decision to execute Operation Torch. see Michael R. Matheny, Carrying the War to the Enemy, 160-64; Rick
} Atkinson, An Army at Dawn, 10-18 
secure the oil fields in the Middle East, and later those in the Caucasus region. ${ }^{168}$ The second centered on the German desire to create fractures within the newly formed alliance between the United States, Great Britain, and Russia. ${ }^{169}$ In order for the Germans to achieve these ambitious strategic objectives, they had to defeat the Allied operational center of gravity, which was the Allied task force itself.

At the beginning of Operation Torch, Rommel and his Afrika Korps were decisively engaged and retreating from Montgomery and the British 8th Army from Egypt into Tunisia. Upon with the defeat and capitulation of the Vichy French in the west, the newly arrived Allied force in Tunisia resulted in pressure on the Axis forces in North Africa from two directions. Rommel could do nothing more than conduct limited tactical actions in an effort to gain time for the reinforcements that Hitler committed to sending him, but by failing to coordinate these tactical actions with other Axis forces he undercut his own chances of achieving operational level success.

Rommel’s limited offensive against the Americans at Faïd Pass and Sidi Bou Zid in February 1943 led to a tactical victory and gave Rommel hope for continued success and the possibility of a deep penetration. However, Rommel failed to understand the lack of logistic supportability of his plan, given the condition of his forces and lack of coordination with reinforcements that could have prevented his culmination after his defeat at Kasserine Pass. Therefore, Rommel could not exploit his initial successes and significantly threaten the American base of operation and lines of communication. ${ }^{170}$

168 Combat Studies Institute, Operation Torch, North Africa Campaign: Offensive, Deliberate Assault, Amphibious, 8 November 1942 (Fort Leavenworth, KS: Combat Studies Institute, 1984), 10.

169 Ibid.

${ }^{170}$ Michael J. Lyons, World War II: A Short History, 3rd ed. (Upper Saddle River, NJ: Prentice Hall, 1999), 191. 
Throughout the North Africa campaign, Rommel displayed a limited understanding of the risks he faced, and he passed up opportunities to mitigate them. He relied upon the element of surprise and overwhelming firepower to achieve tactical victories during the brief period that the American forces offered an easy target. These victories were not in support of, or linked to a larger strategic objective. Commando Supremo (an Italian-led Axis headquarters) had operational control of Rommel and the Afrika Korps, but Rommel disregarded their directives and carried out his own operations, neglecting even to inform his higher headquarters of his plans. ${ }^{171}$ Rommel also refused to coordinate the Kasserine Pass offensive with General Hans-Jürgen von Arnim, the commander sent from Germany to reinforce him. ${ }^{172}$ Rommel's actions left the Germans able only to focus on tactical thinking, while the Americans linked tactical actions to achieve strategic aims, conducting operational art as defined in modern US Army doctrine. The Allied and Axis operations in North Africa directly reflect the education that field grade officers received in their interwar educational system, making the outcome in North Africa unsurprising to the modern historian, even if an Allied success seemed unlikely at the time.

Operation Cobra represents another complex situation where reliance on interwar education assisted in the development of a plan that saved the larger Normandy campaign and perhaps the war. The two principal architects of Operation Cobra, Bradley and Collins, understood that in order to enable the breakout from the Normandy bocage, the Allies had to defeat the German operational center of gravity. Therefore, they focused the planning and execution of Operation Cobra on the defeat of the German panzer divisions on the Normandy

${ }^{171}$ Megargee, Inside Hitler's High Command, 97, 194-95.

172 See Atkinson, An Army at Dawn, 357-392 for an account of the actions and discourse between Rommel and Arnim in the attacks at Sidi Bou Zid and Kasserine Pass, which depicts this point in depth. An additional factor in Rommel's somewhat dysfunctional relationship with Arnim, resides on the fact that Arnim was senior to Rommel at the time of the North Africa Campaign. 
peninsula. ${ }^{173}$ They also developed Cobra as an operation made up of three major phases: the bombardment, the penetration, and the exploitation demonstrating their understanding of the principles of phasing and transition.

The Allies acknowledged the risk that Operation Cobra presented. As in the case of Operation Torch, Bradley and Collins sought to mitigate risk with overwhelming fire support, air superiority, concentration of combat power, and the speed of maneuver warfare. Despite the catastrophe of the Allied preparatory bombing, the flexibility of the Cobra plan allowed for commanders such as Collins and Middleton to make decisions that prevented tactical and operational risks from inhibiting the pursuit and achievement of the strategic objectives. Operation Cobra achieved its operational strategic objectives, despite the escape of a significant number of German forces from the Argentan-Falaise pocket (offset by the destruction of an equally significant number of enemy units). Additionally, Operation Cobra showed that when coupled with experience, the education of US Army officers during the interwar period proved invaluable in enabling success in warfare.

Until the execution of Cobra, the Germans considered the allied center of gravity to be the British forces in and around Caen. The constant fear of a subsequent allied landing at Pas de Calais and the vulnerability of an ensuing allied attack across the Rhine into Ruhr industrial base of Germany fueled this conviction. Therefore, the German operational plan centered on the redistribution of German forces from the south in an effort to reinforce Caen and defeat the British. In support of this, the German forces in the south focused on the attrition and fixing of the Americans in the bocage around St. Lo. While the plan seemed feasible, a lack of understanding of the strategic and operational situation, coupled with the continued success of Allied deception operations that left the Germans convinced that a second amphibious assault at the Pas de Calais

\footnotetext{
${ }^{173}$ William R. Betson, “Centers of Gravity, Lines of Operations, and the Normandy Campaign,” 15.
} 
could happen any time, seriously constrained German action against the Americans when the success of Operation Cobra shifted the Allied operational center of gravity. Additionally, the severely disrupted German lines of communication forced the Germans to accept operational risk in dividing their forces and leaving themselves vulnerable to an American offensive in the south.

The movement of troops to Caen and the corresponding risk surfaced upon the execution of Cobra. Fixed by the British attack during Operation Goodwood and hindered by strained lines of communication, the Germans could execute only a limited response to Cobra, delaying but not preventing the inevitable German retreat. The Germans did conduct a counteroffensive near Mortain from August 7 to 13, but it failed to achieve its objectives of advancing to Avranches and cutting off the American forces that had advanced into Brittany. This failed counteroffensive forced the Germans to spend the remaining days of Cobra in delaying the allied closure of the Argentan-Falaise pocket to allow for the escape of as much combat power as possible.

The German response to Cobra demonstrated a lack of understanding of both theater strategy and operational art. It displayed no clear "pursuit of strategic objectives...through the arrangement of tactical actions in time space and purpose." ${ }^{174}$ Neither did the Germans display an understanding of the relative importance of tactical actions, like the fact that they could not expect to win a campaign or a war through victories at the tactical level alone. The success of the Americans and the failure of the Germans in World War II rested on many strategic, operational, and tactical factors. However, the base of both nations' successes and failures rested on the shoulders of interwar officer education.

${ }^{174}$ ADRP 3-0, 4-1. 


\section{Conclusion}

The Interwar-Period (1919-1939) presented great social, political, and economic changes to the people of the United States and Germany. The armies of both the United States and Germany suffered massive losses in funding, manning, and general popular support. This led both nations to rely on officer education as a means to counter these limitations, implement the lessons from World War I, and prepare their officer corps for the war that loomed on the horizon. Each nation took similar, yet different approaches to the programs they developed to do this.

The United States in a building-block approach relied on CGSS and AWC to create a mid-grade and senior officer corps that understood the function of the general staff, the three levels of war, and the ways to integrate them in support of overarching political objectives. Germany took a similar approach. The German program created an officer corps that understood the general staff and the three levels of war, but lacked formal education in the synchronization and integration of the military objectives in support of political objectives. In light of this, operations in North Africa and Western Europe validated the interwar officer education of the US Army while revealing the weaknesses of Germany's, providing valuable lessons for the future of officer PME.

Operation Torch provides the initial set of implications to officer education. The American planning and execution of Operation Torch demonstrated the importance of synchronized political goals with military objectives, as well as the importance of a coordinated joint and combined staff organization. ${ }^{175}$ The Americans experienced both delays in operations and tactical defeats in follow-on operations in North Africa. However, the Americans still managed to achieve victory in the campaign due to the flexibility and adaptability of the plan and the command structure, which was enabled by an innate understanding of operational art. The

\footnotetext{
${ }^{175}$ Matheny, Carrying the War to the Enemy, 184.
} 
German actions in North Africa demonstrated the relative importance of mastery of doctrine and tactics in warfare. However, as Rommel's actions highlighted, if tactics are not integrated through operational art, then mastery of tactics and doctrine will not equate to overall strategic success. Therefore, Operation Torch and the campaign in Tunisia indicate that officer education must have an aspect of doctrinal and tactical mastery, strong logistical understanding, an emphasis on the intricacies of the three levels of war, and an understanding of joint and multinational operations. These educational outcomes must all coexist within an overarching understanding and instruction of operational art.

While Operation Torch provided the initial set of implications to officer education, Operation Cobra campaign reinforced them. The American planning and execution of Cobra, as well as the German response reconfirms the relative importance of tactical and doctrinal mastery in warfare. However, the actions of the Americans and Germans from Overlord through Cobra once again demonstrated that victory in war does not take place because of tactical expertise alone, but through an understanding and application of operational art. Additionally, Bradley’s and Collins' efforts to understand their current situation, the allied desired end state, and the problems they faced in developing the operational approach implies the importance of design in the execution of operational art. Therefore, future mid-grade officer education must emphasize the incorporation of tactical and doctrinal proficiency in support of the application of operational art, complemented by the recent concept of operational design.

\section{Recommendations for Officer PME}

The Army's recent shift in educational emphasis towards the offense and defensive competencies of decisive action creates challenges as the Army emerges from thirteen years of immersion in conflicts that emphasized counterinsurgency operations. Just as in the Interwar Period, the contemporary field grade officer PME, therefore, must shift in focus while continuing 
to provide an effective education that prepares its officers for future conflict in a complex and unpredictable operational environment. In light of the research provided, this generates three recommendations for the future of field grade officer PME.

The American success and the German failure in World War II illustrates the relative importance of a curriculum that stresses instruction in operational art. The current Command and General Staff College curriculum provides instruction in operational art, presented, however, in a very broad and basic context. Therefore, field grade officer PME should expand in scope to allow for more formalized instruction that enables a deep theoretical and practical understanding of operational art. This will not only assist in strategic and operational planning across the army, but in the creation of adaptive and imaginative staff officers and future commanders.

A direct corollary exists between the American and German officer education programs of the interwar period. While the Germans had a more stringent selection and admission process than the Americans, both nations enforced tough academic standards on their students. Officers in recent years have tended to take the course less seriously in comparison to those of the interwar period. This leads to the second recommendation: reinstitution of the strict academic standards that governed interwar period officer education. This would not only increase the quality of the graduates, but also reinvigorate the significance of education within the US Army’s organizational culture—significance that has arguably declined in recent years.

Historian George Santayana wrote, “Those who cannot remember the past are condemned to repeat it." ${ }^{176}$ During the interwar period, both nations studied military history in an effort to understand past military actions as it contributed to the formation of theory and doctrine. The current United States Army’s PME system includes the study of past wars to improve future

${ }^{176}$ George Santayana, The Life of Reason: The Phases of Human Progress (New York: Charles Scribners Sons, 1905), 284. 
preparation for various possible future contingencies requiring the use of military force. However, the bulk of the instruction covers European military history, specifically that of Prussia and Germany. American military history might not offer an image of immense professionalism and panache like that seen in the tradition of centuries-old fighting cultures. However, American military history does depict a pragmatic use of operational art that befits both the nation's and the Army's culture and fighting style. One can see this in the American planning and execution of Operations Torch and Cobra. Therefore, the third and final recommendation for the future of officer PME rests on the premise of an increased emphasis in the study of American military history. Doing this enables students to achieve a greater appreciation and pride for the history of their nation and chosen profession, while developing a greater understanding of American operational art.

Field grade officer PME in the US Army is as important today as it was during the interwar period. The contemporary operational environment requires a field grade officer that is flexible, adaptive and can think critically and creatively amidst the complex problems the US Army currently faces. This requires a theoretical and doctrinal expertise in the application of operational art. Therefore, as the American and German PME shifted during the interwar period (1919-1939) to account for the changes in warfare, contemporary field grade officer PME must shift to curriculum that is more centric on operational art in order to enable the success of the US Army in future conflict. 


\section{Bibliography}

Army Doctrine Publication 3-0, Unified Land Operations. Washington, DC: Government Printing Office, 2011.

Army Doctrine Reference Publication 3-0, Unified Land Operations. Washington, DC:

Government Printing Office, 2012.

Atkinson, Rick. An Army at Dawn: The War in North Africa, 1942-1943. New York: Henry Holt and Company, 2002.

- The Guns at Last Light: The War in Western Europe, 1944-1945. New York: Henry Holt and Company, 2013.

Ball, Harry P. Of Responsible Command: A History of the U.S. Army War College. Carlisle Barracks, PA: The Alumni Association of the United States Army War College, 1984.

Beaulieu, James A. "The Education of Mid-Career Officers: Building Competency through Professional Military Education.” Masters thesis, United States Military Academy at West Point, 2012.

Betson, William R. "Centers of Gravity, Lines of Operations, and the Normandy Campaign” Master’s thesis, U.S. Command and General Staff College, 1987.

Blumenson, Martin. The Battle of the Generals: The Untold Story of the Falaise Pocket - The Campaign that Should have Won World War II. New York: Morrow Publishing, 1993.

. “A Deaf Ear to Clausewitz: Allied Operational Objectives in World War II.” The U.S. Army War College Quarterly: Parameters 23, no. 2 (Summer 1993): 16-27.

—. European Theater of Operations: Breakout and Pursuit. United States Army in World War II. Edited by Kent R. Greenfield. Washington, DC: Office of the Chief of Military History, 1961.

—. Kasserine Pass. New York: Berkley Publishing, 1983.

_. “Kasserine Pass, 30 January-22 February 1943.” In America’s First Battles, 1776-1965. Edited by Charles E. Heller and William A. Stoft. Lawrence: University Press of Kansas, 1986.

Bradley, Omar N. A Soldier's Story. New York: Henry Holt and Company, 1951.

Breuer, William B. Operation Torch: The Allied Gamble to Invade North Africa. New York: St. Martins Press, 1985.

Carafano, James J. After D-Day: Operation Cobra and the Normandy Breakout. Boulder, CO: Lynne Rienner Publishers, 2000.

Cassidy, Patrick J. “German Officer Strategic Education: A Critical Omission.” Masters thesis, US Army War College, 2002.

Citino, Robert M. Death of the Wehrmacht: The German Campaigns of 1942. Lawrence: University of Kansas Press, 2007. 
- The German Way of War: From the Thirty Years' War to the Third Reich. Lawrence: University of Kansas Press, 2005.

- The Path to Blitzkreig: Doctrine and Training in the German Army, 1920-1939. Boulder, CO: Lynne Rienner Publishers, 1999.

- The Wehrmacht Retreats: Fighting a Lost War, 1943. Lawrence: University of Kansas Press, 2012.

Clausewitz, Carl von. On War. Edited and Translated by Michael Howard and Peter Paret. Princeton: Princeton University Press, 1984.

Combat Studies Institute. Operation Torch, North Africa Campaign: Offensive, Deliberate Assault, Amphibious, 8 November 1942. Fort Leavenworth, KS: Combat Studies Institute, 1984.

Corum, James S. The Roots of Blitzkrieg: Hans von Seeckt and German Military Reform. Lawrence: University Press of Kansas, 1992.

Crozier, David. "Decisive Action: How to Fight and Sustain in the Army's Future Battles.” NCO Journal, May 28, 2013. Accessed January 21, 2015, http://ncojournal.dodlive.mil/ 2013/05/28/decisive-action-how-to-fight-and-sustain-in-the-armys-future-battles/.

D’Este, Carlo. Decision in Normandy. 2nd ed. New York: Harper Perennial Publishing, 1994.

_. Eisenhower: A Soldier's Life. New York: Henry Holt and Company, 2002.

—. World War II in the Mediterranean. Chapel Hill: Algonquin Books of Chapel Hill, 1990.

Doubler, Michael E. Closing with the Enemy: How the GIs fought the War in Europe, 1944-1945. Lawrence: University Press of Kansas, 1994.

Echevarria II, Antulio J. “American Operational Art, 1917-2008.” In The Evolution of Operational Art: From Napoleon to the Present. Edited by John Andreas Olsen and Martin van Creveld. New York: Oxford University Press, 2011.

Finnegan, John Patrick. Against the Spector of a Dragon: The Campaign for Military Preparedness, 1914-1917. Westport, CT: Greenwood Press, 1974.

Forty, George. The Desert War. Gloucestershire, UK: Sutton Publishing Limited, 2002.

Fraser, David. Knight's Cross: A Life of Field Marshal Erwin Rommel. New York: Harper Collins Publishers, 1995.

Gat, Azar. A History of Military Thought: From the Enlightenment to the Cold War. New York: Oxford University Press, 2001.

Gole, Henry G. The Road to Rainbow: Army Planning for Global War, 1939-1940. Annapolis, MD: Naval Institute Press, 2002.

Gorman, Paul F. The Secret of Future Victories. Alexandria, VA: Institute for Defense Analyses, 1992.

Grotelueschen, Mark E. The AEF Way of War: The American Army and Combat in World War I. New York: Cambridge University Press, 2007.

Hacken, Richard and Jane Plotke. "Peace Treaty of Versailles: Articles 159 - 213.” Last modified November 11, 1998. Accessed September 25, 2014. http://net.lib.byu.edu/ rdh7/wwi/ versa/versa4.html. 
Hartcup, Guy. Code Name Mulberry: The Planning, Building and Operations of the Normandy Harbours. New York: Hippocrene Books, 1977.

Hastings, Max. Overlord: D-Day and the Battle for Normandy. New York: Simon and Schuster, 1984.

Herring, Pendleton. The Impact of War: Our American Democracy Under Arms. New York: J.J. Little and Ives Company, 1941.

Hoffman, Karl. Commanders in Focus: Erwin Rommel. London: Brassey’s Publishing, 2004.

Holder, Leonard D. Lt. Gen., and Williamson Murray. “Prospects for Military Education.” Joint Forces Quarterly. No. 18, June 1998. Accessed December 24, 2014. http://www.dtic.mil/doctrine/jfq/jfq-18.pdf.

Howe, George F. Northwest Africa: Seizing the Initiative in the West. United States Army in World War II: The Mediterranean Theater of Operations. Edited by Kent R. Greenfield. 2nd ed. Washington, DC: Office of the Chief of Military History, 1978.

Hughes, Thomas Alexander. Overlord: General Pete Quesada and the Triumph of Tactical Air Power in World War II. New York: The Free Press, 1995.

Kelly, Orr. Meeting the Fox: The Allied Invasion of Africa, from Operation Torch to Kasserine Pass to Victory in Tunisia. New York: J. Wiley Press, 2002.

Kennedy, David M. Freedom from Fear: The American People in Depression and War, 19291945. New York: Oxford University Press, 1999.

- Over Here: The First World War and American Society. New York: Oxford University Press, 1980.

Koistinen, Paul A.C. The Hammer and the Sword. New York: Arno Press, 1979.

- Planning War, Pursuing Peace. Vol. 2, The Political Economy of American Warfare, 1920-1939. Lawrence: University Press of Kansas, 1998.

Lyons, Michael J. World War II: A Short History. 3rd ed. Upper Saddle River, NJ: Prentice Hall, 1999.

Matheny, Michael R. Carrying the War to the Enemy: American Operational Art to 1945. Norman: University of Oklahoma Press, 2011.

Megargee, Geoffrey P. Inside Hitler's High Command. Lawrence: University Press of Kansas, 2000.

Moltke, Helmuth von Graf. Moltke: On the Art of War, Selected Writings. Edited by Daniel J. Hughes. Translated by Harry Bell and Daniel J. Hughes. Novato, CA: Presidio Press, 1993.

Murray, Williamson. “Armored Warfare: The British, French, and German experiences.” In Military Innovation in the Interwar Period, edited by Williamson Murray and Allan R. Millett. New York: Cambridge University Press, 1996.

Muth, Jörg. Command Culture: Officer Education in the U.S. Army and the German Armed Forces, 1901-1940 and the Consequences for World War II. Denton, TX: University of North Texas Press, 2011.

Neillands, Robert. The Battle of Normandy, 1944. New York: Sterling Publishing, 2002. 
Nenninger, Timothy K. "Leavenworth and its Critics: The U.S. Army Command and General Staff School, 1920-1940.” The Journal of Military History 58, (April 1994): 199-232.

—. "A Brief Account of the Evolution of the Regular Course at the U.S. Army Command and General Staff College.” Special Collections, Ike Skelton Combined Arms Research Library, 1988.

Office of Management and Budget. Fiscal Year 2015 Budget of the U.S. Government. Washington, DC: Government Printing Office, 2014.

Olson, John A. and Martin Van Creveld, eds. The Evolution of Operational Art: From Napoleon to the Present. Oxford: Oxford University Press, 2011.

Panetta, Leon E. and Barack Obama. Sustaining Global Leadership: Priorities for the 21st Century Defense. Washington, DC: Government Printing Office, 2012.

Pappas, George S. Prudens Futuri: The US Army War College, 1901-1967. Carlisle Barracks, PA: The Alumni Association of the US Army War College, 1967.

Pearlman, Michael. To Make Democracy Safe for America: Patricians and Preparedness in the Progressive Era. Chicago: University of Illinois Press, 1984.

Petty V., Robert E. “Training VS. Education at the Army War College: The Benefits of a Return to the Past.” Monograph, Command and General Staff College, 2014.

Prados, John. Normandy Crucible: The Decisive Battle that Shaped World War II and Europe. New York: New American Library, 2011.

Santayana, George. The Life of Reason: The Phases of Human Progress. New York: Charles Scribners Sons, 1905.

Schifferle, Peter J. America's School for War: Fort Leavenworth, Officer Education, and Victory in World War II. Lawrence: University of Kansas Press, 2010.

—. "Anticipating Armageddon: The Leavenworth Schools and the United States Army Military Effectiveness: 1919 to 1945.” PhD dissertation, University of Kansas.

Spires, David N. Image and Reality: The Making of the German Officer, 1921-1933. Westport: Greenwood Press, 1984.

Stanford, Alfred. Force Mulberry: The Planning and Installation of the Artificial Harbor off U.S. Normandy Beaches in World War II . New York: William and Morrow Company, 1951.

Training and Doctrine Command Pamphlet 525-3-0, The U.S. Army Capstone Concept. Fort Eustis, VA: Headquarters, Training and Doctrine Command, 2012.

Van Creveld, Martin. Fighting Power: German and U.S. Army Performance, 1939-1945. Westport: Greenwood Press, 1982.

Votaw, John F. The American Expeditionary Forces in World War I. New York: Osprey Publishing, 2005.

Weigley, Russell F. "Normandy to Falaise: A Critique of Allied Operational Planning in 1944.” In Historical Perspectives of the Operational Art. Edited by Michael D. Krause and R. Cody Phillips. Washington, DC: Center for Military History, 2007.

Weinberg, Gerhard. A World at Arms: A Global History of World War II. New York: Cambridge University Press, 1994.

—. Germany, Hitler \& World War II. Cambridge: Cambridge University Press, 1996. 
Whitting, Charles. Disaster at Kasserine: Ike and the 1st (US) Army in North Africa 1943. 2nd ed. South Yorkshire, UK: Leo Cooper, 2003.

Wilburn, F.W., trans. Truppenführung. Part I. Special Collections: Ike Skelton Combined Arms Library, 1933. Accessed October 23, 2014.

Wilt, Alan. “The Air Campaign.” In D-Day, 1944, Edited by Theodore A. Wilson, 2nd ed., 134154. Lawrence: University Press of Kansas, 1994.

Zaloga, Steven J., and Michael Weply. Kasserine Pass, 1943: Rommel's Last Victory. Oxford: Osprey Publishing, 2005.

Zaloga Steven J., and Tony Bryan, Operation Cobra: Breakout from Normandy. Oxford: Osprey Publishing, 2001. 